\title{
The effect of brine pumping on the natural hydrodynamics of the Salar de Atacama: The
} damping capacity of salt flats

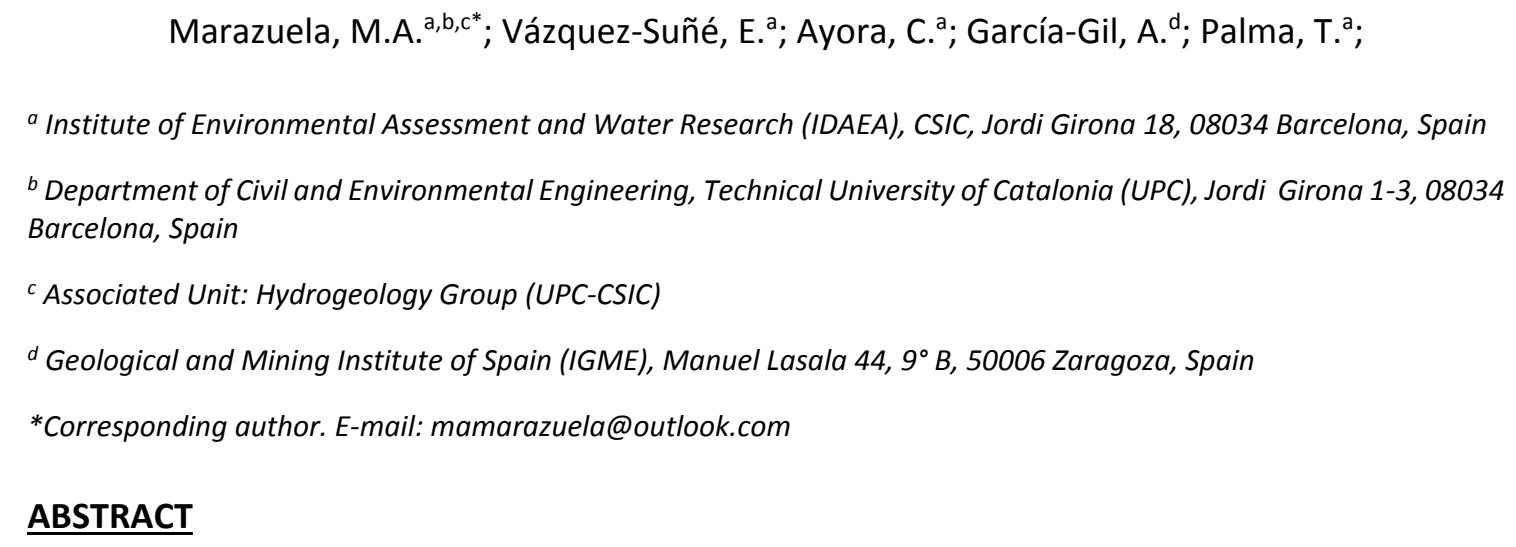

\section{ABSTRACT}

The Salar de Atacama is used as a case study to analyse and quantify coupled natural (evaporation and recharge) and anthropogenic processes (pumping of lithium-rich brine) to abstract their patterns to other salt flats using a three-dimensional groundwater flow model. Important changes in the dynamics of the water table between the pre-operational period (1986-1994) and operational period (1994-2015) are observed. The water table exhibited a gradual drawdown during the pre-operational period because the evaporation was greater than the recharge for most of these periods. This negative balance was counteracted by some sharp rises that were produced by direct rainfall events on the salt flat. The deep lateral recharge that arrived from the mountains did not produce abrupt changes in the water table because the rain events in the mountains were damped by the distance of the recharge zone and great thickness of the unsaturated zone.

The natural evolution of the water table was modified by the intensive brine pumping that was performed in the south-western Salar de Atacama during the operational period. As evaporation depends on the water table depth, the pumping caused a drawdown of the water table, resulting in an evaporation rate reduction that partially compensated for the pumped brine in the water balance of the basin. This effect is defined as the damping capacity of salt flats. Thus, salt flats have a high capacity for dampening oscillations in their water table in response to both natural and anthropogenic disturbances which is of great importance for the management of lake and wetland ecosystems and brine exploitation. The limit of the dampening capacity of salt flats is defined by the evaporation extinction depth, which is in the range of 0.5-2 m. 


\section{DAMPING CAPACITY} of the salt flats water table

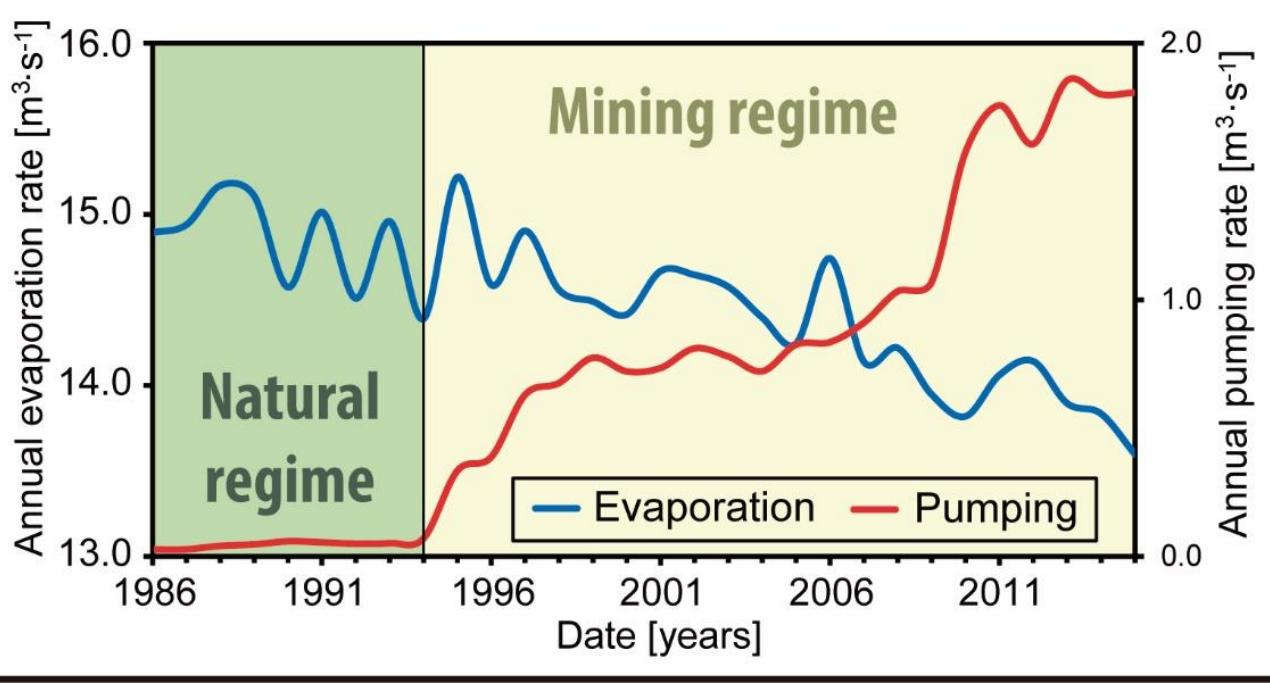

KEYWORDS

Groundwater management, numerical modelling, evaporation, brine, pumping, lithium.

$\underline{\text { HIGHLIGHTS }}$

- 3D groundwater flow modelling of the Salar de Atacama.

- Damping capacity of salt flats water table was defined.

- Brine pumping causes reduction in the evaporation rate of salt flats.

- Reduction of evaporation due to brine pumping damping the water table drawdown. 
The Salar de Atacama is the largest source of lithium in the world, containing approximately a quarter part of the global reserves. It is, behind the Salar de Uyuni (Bolivia) and Salinas Grandes (Argentina), the third largest salt flat of the Altiplano and of the world (Risacher et al., 2003). Brine of salt flats is also a source of large amounts of boron, potassium, iodine, sodium chloride and bischofite (Evans, 1978; Hardie, 1991; Kesler et al., 2012; Lowenstein and Risacher, 2009; Munk et al., 2016; Rissmann et al., 2015). These elements and minerals are essential for the production of batteries, fertilizers, ceramics, detergents and other important industrial utilities (Marom et al., 2011; Vikström et al., 2013). The exploitation of lithium and other chemical elements is executed through brine pumping. The extracted brine is channelled into large pools where it evaporates and precipitates salts, returning a part of the excess brine to the aquifer via infiltration. The boom in clean energy production forecasts an increase in the demand for these elements and minerals that could trigger significant ecological impacts on salt flat ecosystems. Therefore, understanding the hydrodynamics of these hydrogeological systems is important for predicting their response to anthropogenic pressure and for proposing solutions for their sustainable management.

Salt flats are saline dry lakes often associated with arid to hyperarid environments in which the water table is located close to the land surface, allowing phreatic evaporation from groundwater. Under the natural regime, the depth of the water table is a result of the balance between the recharge produced mainly by rainfall in the mountains and the evaporation produced in the salt flat (Yechieli and Wood, 2002). The high evaporation rates maintained for thousand or millions of years allow the accumulation of large amounts of salts (Corenthal et al., 2016; Warren, 2010; Wood and Sanford, 1990).

As a consequence of the density contrast between the brine produced from evaporation and the freshwater recharged in the mountains, a saline interface with a mixing zone is often present in the margins of the salt flats (Fan et al., 1997; Hamann et al., 2015; Holzbecher, 2005; Nield et al., 2008; Wooding et al., 1997). When the groundwater recharged in the mountains arrives at the marginal zone of the salt flat, it is forced upward by its lower density. In the marginal zone where the mixing zone is located, many lakes and wetlands with valuable ecosystems exist, favoured by the upward groundwater flow. Moreover, in the salt flat, the evaporated brine sinks due to its high density, and when it arrives at the mixing zone, it can be forced to return to the land surface of the mixing zone by convection cells, causing mixing with the freshwater that comes from the mountains (Marazuela et al., 2018). 
As the salt flats water table is controlled by evaporation and recharge processes, these systems are very sensitive to climatic and anthropogenic changes (Rosen, 1994). Climatic cycles may cause a direct response in hydraulic heads at different scales (Bowen et al., 2017; Duffy and AlHassan, 1988). Moreover, the anthropogenic pressure upstream of the salt flats or directly in the same salt flat can generate large disturbances to the water table (Acosta and Custodio, 2008; Tyler et al., 2006) and therefore in the ecosystems depending on it. The study of some of these processes that join in the hydrodynamics of salt flats has been addressed in a separate manner in previous studies. Such is the case for the evaporation and rainfall in the Altiplano. Evaporation occurs directly from the groundwater due to the shallow water table, which favours the rise of water by capillarity. The evaporation in salt flats can reach the potential evaporation rate in open water reservoirs, but this rate decreases exponentially until extinguishing in the range of 0.6-2 meters of depth (Kampf et al., 2005; Kampf and Tyler, 2006; Muñoz-Pardo et al., 2004). This causes the fluctuations of the water table due to natural or anthropogenic processes to modify the evaporation rate. Rainfall in the Altiplano basins is conditioned by topography, which, due to the Altiplano uplift, results in two rainfall domains, one more arid at lower elevations and another wetter one at high elevations (Bookhagen and Strecker, 2008; Boutt et al., 2016; Houston, 2006; Rech et al., 2006). To the best of the authors' knowledge, there are no studies that integrate in a coupled manner all natural processes with the pumping of brine. Based on numerical models, Muñoz-Pardo et al. (2004) developed a direct relationship between the water table depth and recharge and evaporation and investigated how this relationship could contribute to keeping the water table stable, but a detailed study of this process and the effect of brine pumping is still lacking. Acosta and Custodio (2008) evaluated the environmental impacts under different pumping rates in the exploitation of the Salar de Huasco (Chile), although they could not compare with measured data for the case studied.

Numerical models are the best tool capable of integrating all components of the water balance to analyse its interactions and to quantify the effects that brine pumping has on the water table. No previous study has integrated all natural and anthropogenic processes at the same time to reproduce the water table evolution of a salt flat in a three-dimensional (3D) numerical model. Additionally, no study has analysed the response of salt flats to the intensive pumping of brine and how this affect the natural regime of the water table. The high computational cost and the difficulty of quantifying the water balance of these basins are the reasons why these systems have rarely been quantitatively modelled.

To fill this scientific gap, the Salar de Atacama is a suitable case study. The monitoring network of the Salar de Atacama is considered the largest in the world (Tyler et al., 2006), and it has 
hydraulic head and density data spanning more than 30 years. The range of the continuous data record covers a first period (1986-1994) in which the hydrodynamics of the system were dominated by natural processes (the pre-operational period in an almost-natural regime) and a second period (1994-2015), in which the effect of the intensive extraction of brine was added (the operational period in the anthropogenic regime).

Marazuela et al. (2018) used the Salar de Atacama to describe the hydrodynamics of the mixing zone in salt flats and to propose a methodology of hydraulic head corrections based on density variations to approximate the vertical fluxes of the mixing zone in constant-density 3D numerical models at the regional scale. This allows overcoming the limitation of the high computational cost of 3D models with variable density. Furthermore, the 3D steady-state numerical model of Marazuela et al. (2019) established the average water balance and groundwater flow of the Salar de Atacama in its natural regime, which serve to evidence that the infiltration in hyperarid basins reaches values much higher than what was previously believed. In their work, the water balance of the Salar de Atacama basin was established to be $16 \mathrm{~m}^{3} \cdot \mathrm{s}^{-1}$ for both the recharge and evaporation, allowing a $0 \mathrm{~m}^{3} \cdot \mathrm{s}^{-1}$ net balance. However, the temporal evolution of the water table and the effect of the hydrodynamics of the natural processes coupled to the brine pumping were outside the scope of the research and have not yet been studied. Understanding how brine pumping has affected the natural hydrodynamics of the Salar de Atacama for more than three decades is of great importance to know how salt flats respond to anthropogenic pressure and how this may affects their ecosystems. This is of paramount importance because salt flats (and their ecosystems) are becoming increasingly targeted for mining raw material critical for modern industry.

The objective of this paper is to study the interaction between the natural and anthropogenic processes that coexist in salt flats, using the Salar de Atacama as a case study, and to abstract natural and anthropogenic patterns to other salt flats. For this purpose, a 3D transient-state numerical model is used as a tool to describe and quantify the water table response to these coupled processes.

\section{STUDY AREA}

The Salar de Atacama basin is located in a large endorheic basin of the current forearc of northern Chile. The surface area of the basin is approximately $17,000 \mathrm{~km}^{2}$, and its depocenter (2300 m a.s.l., meters above sea level) is the Salar de Atacama. It belongs to the Antofagasta Region, located $55 \mathrm{~km}$ south of San Pedro de Atacama and $320 \mathrm{~km}$ northeast of Antofagasta 
150 (Figure 1). The basin may be divided into four geomorphological domains: salt flat nucleus, 151 mixing zone, alluvial fans and basement and volcanic rocks.

152

153

154

155

156

157

158

159

160

161

162

163

164

165

166

167

168

169

170

171

172

\section{FIGURE 1}

The eastern limit of the basin is represented by the Western Cordillera, which is the current volcanic arc of the Andean Range and reaches 5,000 $\mathrm{m}$ a.s.l. The western limit of the basin is the Cordillera Domeyko, which has an average elevation of 3,000 m a.s.l. and is constituted by Palaeozoic and Mesozoic rocks (Arriagada et al., 2006; Pananont et al., 2004). At its southern boundary, the basin is limited by the Cordón de Lila, which includes igneous and sedimentary rocks from the Ordovician to the Carboniferous (Muñoz et al., 2002). The Miocene and Pliocene ignimbrites along with some Upper Paleozoic rocks outcrop on the slope of the Western Cordillera (Mpodozis et al., 2005).

The current depocenter of the basin is mainly filled by clastic and evaporite sediments that, due to the continuous lateral groundwater recharge coming from the mountains and permanent evaporation, have generated a nucleus enriched in sodium chloride of area $1,360 \mathrm{~km}^{2}$. The nucleus is surrounded by a marginal zone that corresponds to the intersection between the mixing zone and the land surface. The mixing zone has an area of approximately $2,000 \mathrm{~km}^{2}$, and it is constituted by halite, gypsum and calcite (Vásquez et al., 2013).

\subsection{Hydrogeology}

As an endorheic basin, all recharge that occurs in the aquifers of the Salar de Atacama is produced by infiltration of rainfall. Because the Andean Range acts as a barrier to the cold Humboldt Current of the Pacific coast, the Salar de Atacama is under a subtropical high-pressure zone, and it has a hyperarid climate that is characterized by low precipitation rates.

The surface hydric network is scarce, and the highest flows occur in the San Pedro and Vilama rivers (Figure 1). The San Pedro River forms an alluvial fan (San Pedro alluvial fan) when arriving at the northern margin of the salt flat, where water infiltrates detrital sediments. Additionally, there are some intermittent streams that drain, across the eastern margin, the water from the mountains such as the Toconao, Aguas Blancas, Talabre, Camar, Socaire, Peine and Tilomonte streams. At a short distance from San Pedro alluvial fan, and in the east direction, the Burro Muerto Channel connects and feeds the Chaxa and Barros Negros Lakes which constitute the Soncor Lake system.

In addition to Soncor, there are several lakes (Cejar, Tebenquiche, Aguas de Quelana, Peine and Tilopozo) in the mixing zone associated with the upward flows that constitute highly valuable 
ecosystems that serve as a habitat or nesting centre for Andean flamingos and other species (Cornellà et al., 2009; Ortiz et al., 2014; Salas et al., 2010; Tejeda et al., 2003) (Figure 2). Marazuela et al. (2018) differentiated three hydrodynamic zones inside the mixing zone: an internal mixing zone (IMZ), middle mixing zone (MMZ) and external mixing zone (EMZ). Most of the lakes are located in the upstream flows associated with the middle mixing zone (MMZ), which separates the internal mixing zone (IMZ) from the external mixing zone (EMZ) (Figure 1). The IMZ exhibits a hydrodynamics dominated by groundwater movements associated with density contrasts. On the other side, the EMZ is controlled by the groundwater flows coming from the recharge in the mountains (Marazuela et al., 2019). The water table depth in the natural regime ranges from 0.1-1 $\mathrm{m}$ in the salt flat nucleus and 0-1.5 $\mathrm{m}$ in the mixing zone.

In the nucleus, the most permeable aquifer is the upper stratigraphic unit of halite (Figure 2) (IDAEA-CSIC, 2017; Marazuela et al., 2019). Below, a second halite aquifer is confined by a low permeability stratigraphic unit of gypsum that constitutes an intermediate aquitard. Towards the margins, the hydro-stratigraphic sequence aquifer-aquitard-aquifer is transferable to the alluvial fans as a regional simplification, where the upper and lower high-permeability detrital deposits are detached from the lower ones by a poorly permeable layer constituted mainly by sands, silts and ashes. Two main faults affect the thickness and geometry of these stratigraphic units, the Salar and Tucúcaro faults.

\section{FIGURE 2}

\section{MATERIALS AND METHODS}

In this section, the methodology followed to obtain the data used for the estimation and calibration of the inflows and outflows of the numerical model is described. First, the meteorological data considered for the estimation of recharge, evaporation and flow of streams are explained. Second, we address the hydrogeological data, which include the pumping rate of the brine and freshwater wells, the hydraulic heads of the observational wells and the hydraulic parameters involved in the calibration process of the numerical model. Finally, the geometry and performance of the 3D transient-state numerical model are described.

\subsection{METEOROLOGICAL DATA}

\subsubsection{Recharge}

The rainfall data were provided by 14 weather stations located in the Salar de Atacama basin (see their locations in Figure 3A). Some rain events affect a very local area, and analysing the rainfall over time in an integrated manner is not possible. Therefore, each rain event from 
January 1986 to December 2015 was mapped individually. Thus, an isohyets map of each event

215 was created, taking into account topographic factors as the dominant criteria for the 216 interpolation.

\section{FIGURE 3}

218 Two multivariate methods were used to fill gaps in the rainfall time series: weighted linear 219 combination (Peterson and Easterling, 1994) and the Karl methodology (Karl and Williams, 220 1987). The first method allows filling the gaps from the data of statistically proximal series by 221 means of a weighted linear combination of the series that are used. The second method replaces 222 the gap of a record by the corresponding value of another nearby station that has a high linear 223 correlation index, it being necessary to know the behaviour of precipitation in the basin (e.g. 224 rainfall gradient).

The recharge by infiltration of rain water was calculated by subtracting the detention from the total precipitation following the criteria of Marazuela et al., (2019). In accordance with this previous work, the Salar de Atacama basin cannot be treated as a typical hyperarid area with very low infiltration rates and a homogeneous precipitation rate. The sparse vegetation, the underdeveloped surface hydrological network and the high degree of fracturing of the rocks of the mountains (the main recharge area) imply that the great part of the rainfall infiltrates in the mountains. Detention is the proportion of rainfall that will not arrive to infiltrate and recharge the aquifers. At the beginning of each precipitation event, approximately $5 \mathrm{~mm}$ are detained in the soil and return to the atmosphere by evaporation. This value is justified because rain events lower than $5 \mathrm{~mm}$ almost never affect the water table of the salt flat because the water is detained in the soil and subsequently evaporated. This value was subtracted for each rain event. The zoning to quantify the recharge by rainfall was performed at two levels: (1) peripheral subbasins and (2) the salt flat nucleus, mixing zone and alluvial fans. The first correspond to the most elevated areas located between 2,400 and 5,500 m a.s.l. The sub-basins of greater extension and elevation are found in the eastern half of the basin. In these areas, andesite and ignimbrite rocks appear interspersed with continental sedimentary facies. They constitute aquifers of low hydraulic conductivity and storage capacity, although they can increase their effective hydraulic conductivity due to the high degree of fracturing. As explained above, the high degree of fracturing together with the scarce vegetation and the processes of physicalchemical weathering on the surface make the infiltration rate very high. A total of 11 sub-basins were defined based on a morphometric study that included a digital elevation model and satellite images (LANDSAT 7 and 8) (Figure 3A). On the other hand, the domain that 
encompasses the salt flat nucleus, mixing zone and alluvial fans was discretized into 30 zones

248 according to geomorphological and soil features (Figure 3B). The recharge values for sub-basins

249 are listed in Table S1, and those for surface zones are presented in Table S2.

\subsubsection{Evaporation}

251 The evaporation in the Salar de Atacama occurs from the water table which is very close to the ground (phreatic evaporation). The higher evaporation rates, however, occur in the mixing zone where the water table is closer to the land surface and where some lakes allow direct evaporation. In the salt flat nucleus, the polygonal structure of the salt crusts allows the rise of the groundwater by capillarity and favours evaporation from the water table when it is close to the surface. Although the evaporation rate in the nucleus is much less than in the mixing zone, this should not be neglected because the surface area is very large.

Evaporation rates were estimated from the experimental data registered by evaporation trays and lysimeters. Evaporation trays were installed in the weather stations. Lysimeters were installed in the mixing zone to measure the evaporation from the groundwater. Evaporation rates were correlated with the water table depth by fitting the experimental data of the Iysimeters with the Philip (1957)-type curve. This method relates the evaporation rate that is measured to the water table depth through an exponential fit.

Considering the characteristics of each type of soil and the data collected by the evaporation trays or evaporimeter tanks, the annual evolution of the evaporation rate in each zone of the Figure 3B was established. The average values for each zone are listed in Table S2.

\subsubsection{Streams}

Although the surface drainage network is undeveloped in the Salar de Atacama basin, two rivers and some streams may be identified. Streams descend from the eastern mountains until the alluvial fans, where the often intermittent flows infiltrate as a consequence of the high permeability. These streams were continuously monitored using 15 gauging stations (see their locations in Figure 1). Time series gaps were filled through data correlation between nearby gauging stations, taking into account the average value of each stream and the meteorological data of the weather stations. The highest flows are in the San Pedro River, with $0.72 \mathrm{~m}^{3} \cdot \mathrm{s}^{-1}$, and the Vilama River, with $0.28 \mathrm{~m}^{3} \cdot \mathrm{s}^{-1}$, both of them at the north of the Salar de Atacama. The other streams, such as Toconao, Aguas Blancas, Talabre, Camar, Socaire, Peine and Tilomonte, are located on the eastern or south-eastern side of the Salar de Atacama, with flow rates that range between $0.15 \mathrm{~m}^{3} \cdot \mathrm{s}^{-1}$ and $0.01 \mathrm{~m}^{3} \cdot \mathrm{s}^{-1}$. The average values of streams are presented in Table S3. 
280

281

282

283

284

285

286

287

288

289

290

291

292

293

294

295

296

297

298

299

300

301

302

303

304

305

306

307

308

309

\subsubsection{Pumping wells}

At present, two mining companies pump the brine of the Salar de Atacama. These companies are Sociedad Química y Minera de Chile S.A. (SQM), owner of mining plants MOP and SOP and Albemarle Corporation (ALB), owner of mining plant ALB.

The pumping network of SQM consists of several hundred brine pumping wells located in the southwestern salt flat nucleus, 5 freshwater wells in the eastern alluvial fans and 4 reinjection points associated with infiltration from the evaporation pools (Figure 1). Daily flow rates are available from the beginning of the pumping in 1994.

The pumping network of the ALB mining company comprised 62 brine wells in the southern salt flat nucleus and 3 freshwater wells in the southern alluvial fans. Historical flows were seasonally represented based on the data presented in Rockwood-Lithium (2015).

The brine pumping performed by ALB began in 1983 at a rate of $0.05 \mathrm{~m}^{3} \cdot \mathrm{s}^{-1}$ and increased to $0.13 \mathrm{~m}^{3} \cdot \mathrm{s}^{-1}$ by 2015 . The extraction of brine performed by SQM began in November 1994 at a rate of $0.07 \mathrm{~m}^{3} \cdot \mathrm{s}^{-1}$ and reached $1.37 \mathrm{~m}^{3} \cdot \mathrm{s}^{-1}$ in 2015 , with the maximum extraction in summer and minimum in winter (Comisión Regional del Medio Ambiente, 2006; IDAEA-CSIC, 2017). The freshwater pumping performed by ALB ranged between $0.01 \mathrm{~m}^{3} \cdot \mathrm{s}^{-1}$ in 1999 and $0.02 \mathrm{~m}^{3} \cdot \mathrm{s}^{-1}$ in 2015 , and for SQM, it ranged between $0.07 \mathrm{~m}^{3} \cdot \mathrm{s}^{-1}$ in 2000 and $0.21 \mathrm{~m}^{3} \cdot \mathrm{s}^{-1}$ in 2015 . The SQM reinjections increased from $0.1 \mathrm{~m}^{3} \cdot \mathrm{s}^{-1}$ in 1996 to $0.38 \mathrm{~m}^{3} \cdot \mathrm{s}^{-1}$ in 2015 . Therefore, a pre-operational period (1986-1994) and an operational period (1994-2015) were differentiated. In the preoperational period some brine extractions occurred, but they were insignificant compared with those that have occurred since 1994.

\subsubsection{Observational wells}

The hydraulic head time series were recorded manually or with a data logger in a total of 549 wells (see their locations in Figure 1). The data were corrected for variable density variations following the methodology of Marazuela et al., (2018). This methodology is based on the application of a correction to the fresh and mixed water heads to compensate for the density variations, taking as reference the density of the brine $\left(1.23 \mathrm{~kg} \cdot \mathrm{L}^{-1}\right)$.

\subsubsection{Hydraulic parameters}

Evaporites and cemented detrital deposits of salt flats have low hydraulic conductivities if they are not altered. However, the dissolution and karstification increase the permeability by several 
orders of magnitude, resulting in preferential channels (Bakalowicz, 2005). These deposits can

311 be treated as discretized equivalent porous media in regional studies (Scanlon et al., 2003).

312 The reference values of the hydraulic conductivity and specific storage were deduced from the hydraulic tests performed by mining companies and in some cases reinterpreted by other authors (IDAEA-CSIC, 2017; Marazuela et al., 2019; Rockwood-Lithium, 2015). The zoning of the hydraulic parameters and specific storage was performed based on lithological and soil features, pumping test results and the previous study (Figure 4).

\section{FIGURE 4}

\subsection{NUMERICAL MODELLING}

A transient-state groundwater flow model was constructed to reproduce the hydrogeological behaviour of the Salar de Atacama between January 1986 and December 2015, considering the natural (recharge and evaporation) and anthropogenic processes (freshwater and brine pumping and reinjections). For the initial condition, the steady-state water table presented by Marazuela et al. (2019) was used, which represents the average hydraulic heads in the natural regime, prior to brine pumping, similar to the 1986 regime. A time step limited to 10 days was applied. The FEFLOW code (Diersch, 2014) was used to solve the three-dimensional groundwater flow equation.

\subsubsection{Model set-up}

The model domain (Figure 1) has an area of $3,303 \mathrm{~km}^{2}$ and covers the salt flat nucleus, the mixing zone and a large part of the eastern alluvial fans. The eastern boundary is the contact between the alluvial fans and the basement or volcanic rocks, the southern boundary is the contact between the salt flat nucleus and the Cordón de Lila, the western boundary is the contact with the Cordillera de la Sal and the northern boundary correspond with a deep structural lineament, sufficiently far from the area of interest (IDAEA-CSIC, 2017).

The three-dimensional mesh contains four layers with a total of 266,340 triangular prism elements to represent aquifer $A$, aquitard $A B$ and aquifer $B$ (Figure 5). Aquifer $A$ and aquitard $A B$ are represented with one layer each. Aquifer B is represented through the two lower layers to correctly reproduce the strong fault jump caused by the Salar fault. The mesh is refined near fault jumps, lakes, pumping wells and observational wells. The sizes of the elements range between 10 and $300 \mathrm{~m}$. 
342 The lateral groundwater recharge that represents the flows coming from the water recharged 343 in the mountains was implemented through the well-type boundary condition around the 344 domain for each sub-basin. Due to the distance between the mountains and the model domain 345 and due to the thick unsaturated zone in the mountains, these values were constant over time. 346 The recharge produced by the rainfall events that occurred directly in the model domain, due to 347 the thin unsaturated zone, was incorporated as a Neumann-type boundary condition. Therefore, 348 for each defined recharge zone on the top boundary of the model, a time series with the 349 estimated recharge values of each rain event was obtained.

350 The evaporation was incorporated through double boundary conditions, outflow on top and 351 Cauchy-type. The outflow on top was used to implement the time series of the evaporation rate 352 in each zone of the nucleus and mixing zone, including lakes. The evaporation time series 353 included a progressive non-linear reduction in the salt flat nucleus due to the deepening of the water table produced by the pumping. The Cauchy-type boundary condition with a high leakage served to prescribe the hydraulic head in the Soncor Lake system and in the MMZ, where the water head was similar to the salt flat nucleus over time. The northern stretch of the mixing zone mapped in Figure 1 was not taken into account for the Cauchy boundary condition (Figure 3B) because the water heads change with respect to the nucleus, and it would be necessary to apply density corrections to the prescribed water heads. The outflow from this zone was considered based on the calibrated value of the Neumann-type boundary condition.

361 Finally, a well-type boundary condition was used to reproduce the extractions and reinjections.

362 The brine pumping wells were adjusted to a simplified network of equivalent wells to facilitate 363 their implementation in the numerical model. This network of equivalent wells was made using 364 a regular mesh with cells of $1 \mathrm{~km}^{2}$ resolution, assigning the accumulated pumping of the wells 365 in each cell to its centroid (Figure 6). This methodology was performed independently for aquifer 366 A and aquifer B. A total of 245 equivalent wells were used.

\section{FIGURE 6}

\subsubsection{Model calibration}

369 The calibration process was performed through inverse modelling with the parameter 370 estimation code PEST (Doherty, 2015). The core of the PEST engine is the Gauss-Levenberg371 Marquardt algorithm (GLMA), which iteratively optimizes the model parameters to improve 372 their fit to observed data by means of an objective function. 
373 The calibration of the hydraulic conductivity, lateral recharge and average evaporation was a

374 joint process based on the steady-state model of Marazuela et al. (2019). The specific storage 375 was calibrated for the transient-state model.

376 The hydraulic conductivities in aquifer A exhibited values ranging between 80 and $300 \mathrm{~m} \cdot \mathrm{d}^{-1} \mathrm{for}$ 377 the alluvial fans and between 60 and $300 \mathrm{~m} \cdot \mathrm{d}^{-1}$ for the salt flat nucleus and mixing zone (Table 378 S4). The hydraulic conductivities in aquitard $A B$ ranged between 0.01 and $5 \mathrm{~m} \cdot \mathrm{d}^{-1}$, and in aquifer $379 B$, they ranged between 0.1 and $20 \mathrm{~m} \cdot \mathrm{d}^{-1}$. The specific storage values (Table S5) ranged between $3800.007 \mathrm{~m}^{-1}$ and $0.012 \mathrm{~m}^{-1}$ in aquifer $A$. For aquitard $A B$ and aquifer $B$, the specific storage was $10^{-}$ $381{ }^{4} \mathrm{~m}^{-1}$ and $10^{-5} \mathrm{~m}^{-1}$, respectively.

\section{RESULTS AND DISCUSSION}

In this section, the field data combined with the results of the 3D transient-state numerical model are used to discuss the natural hydrodynamics of the Salar de Atacama and how the brine pumping has impacted the natural water table to abstract patterns applicable to other salt flats.

First, the individualized natural processes, recharge and evaporation, that occurred in the Salar de Atacama and their coupled behaviour are addressed separately. Subsequently, the effects that caused brine pumping are evaluated and discussed to extrapolate general patterns to other salt flats.

\subsection{NATURAL HYDRODYNAMICS OF THE SALAR DE ATACAMA}

The results of the numerical model simulation show the evolution of the water table of the Salar de Atacama from 1986 to 2015, taking into account the brine pumping (Figures 7 and 8). The brine pumping was almost non-existent until 1994, and therefore it is very interesting to first establish the natural hydrodynamics of the salt flat during this period (1986-1994) to be able to discuss in the following section the anthropogenic impacts of brine pumping.

FIGURE 7

In the natural regime, the water table is controlled by evaporation and recharge processes. The experimental data reveal that the evaporation has a clearly seasonal behaviour, with average minimum values of $1050 \mathrm{~mm} \cdot \mathrm{yr}^{-1}$ from June-July and maximum values of $4450 \mathrm{~mm} \cdot \mathrm{yr}^{-1}$ from December-January. In addition to this annual evaporation wave, there is a daily day-night cycle 
extinguishing at water table depths between 0.5 and $2 \mathrm{~m}$, as evidenced by the lysimeter data

404 (Figure 9).

405

406

407

408

409

410

411

412

413

414

415

416

417

418

419

420

421

422

423

424

425

426

427

428

429

430

431

432

433

434

\section{FIGURE 9}

The evaporation process is apparent in the water table evolution mainly as an annual cycle. Thus, the greater evaporation in summer than in winter causes a gradual drawdown from December to June and a gradual rise from June to December. The phase of the sinusoidal effect may change slightly depending on the salt flat zone if any external factor, such as the lateral groundwater recharge that arrives from the mountains, generates a change in the water table depth. In Figure 10 , the correlation between the hydraulic heads and the normalized evaporation function applied for each average value of evaporation is shown. This normalized function was computed based on the evaporation data of the open water reservoir (evaporation trays data). The water table oscillations due to the annual cycle of evaporation reach a half metre in the mixing zone, where the water table is closest to the topographic surface and the evaporation rate is higher (Figure 8). However, in most modelled areas the maximum oscillation caused by evaporation is centimetres or a few decimetres. This effect can be observed in detail in the observed and modelled hydraulic heads shown in Figure 8 during the pre-operational period. The wells P1, P2 and P3 located in the north-eastern mixing zone exhibit higher oscillation ranges due to evaporation, which is approximately 0.10 to $0.50 \mathrm{~m}$. Additionally, the annual cycle of evaporation is evidenced in the wells $\mathrm{P} 5, \mathrm{P} 10$ and $\mathrm{P} 11$, with amplitudes from approximately 0.10 to $0.30 \mathrm{~m}$ for the eastern and south-eastern mixing zones. Furthermore, during the preoperational period, this cycle is also evidenced in the wells P4, P6, P7 and P9 of the brine pumping area, with oscillation rates between 0.10 and $0.20 \mathrm{~m}$. These field data confirm that in the natural regime, both the nucleus and the mixing zone evaporated the groundwater. The mixing zone experienced a higher evaporation rate due to the shallower water table and the existence of lakes connected to the water table. This is coherent with the lower amplitude of the evaporation cycle in the salt flat nucleus relative to the mixing zone.

\section{FIGURE 10}

The meteorological data provided by the weather stations reveal that rainfall rate ranged from less than $10 \mathrm{~mm} \cdot \mathrm{yr}^{-1}$ in the salt flat nucleus to greater than $160 \mathrm{~mm} \cdot \mathrm{yr}^{-1}$ in the eastern mountains (Figure 3A). The rainfall events are very scarce, and they are concentrated from December to March. The amount of precipitation is controlled by the climatic cycles, and it is subject to cycles of 5, 10 or more years, coinciding also with the El Niño - Southern Oscillation (ENSO). In the salt 
flat nucleus, the precipitation decreases from north to south and from east to west, since the clouds discharge the water before reaching the south-western end of the salt flat.

437 The effect of the rainfall recharge on the water table depends on its location. Rain events can 438 occur both directly on the salt flat nucleus and mixing zone or in the mountains. An abrupt and instantaneous rise in water table is observed with each direct rain event on the salt flat nucleus and the IMZ due to the small thickness of the unsaturated zone. However, some rain events exhibit no direct impact on the water table or a linear relationship between the amount of rainfall and the disturbance of the water table (Figure 11). This behaviour is a consequence of the type of soil, the spatial distribution of the rain event and the temporal lag between rainfall events which modify the detention. Owing to the great extent of the basin, the rain events did not present a homogeneous distribution along the entire basin, making it necessary to analyse the isohyets map for each event and translate this into the time series of the numerical model. Thus, rain events with high rainfall rates and great spatial extent (rain events identified at several weather stations) are those that give rise to greatest abrupt rises of the water table (Figure 11). This type of perturbation can trigger abrupt ascents of several decimetres of the water table, as observed in Figures 8 and 11. Black arrows denotes each of the rain events than caused a strong rise of the water table, with eight being the most important during the last 30 years.

Regarding the rain events that occurred in the mountains, however, the perturbation that they produced in the water table of the salt flat is not obvious. There, the rain water infiltrates the soil and recharges aquifers. The amount of water recharged in the eastern mountains is very large due to the low detention in the soil caused by the presence of fractured soils (ignimbrites) and the scarce vegetation. However, despite the large volume of water recharged, the perturbations to the water table were not evident in the salt flat. This is because due to the greater thickness of the unsaturated zone in the mountains and the distance from the mountains to the salt flat nucleus, the effect of the rain events is damped.

In the salt flat nucleus and the IMZ, the coupling of both natural processes, evaporation and recharge, results in a water table evolution dominated by a gradual decay due to evaporation which is disrupted by sudden level rises caused by episodic rain events. The natural trend of the water table is to gradually decay because the evaporation is greater than the recharge for most of the time period studied. This effect is evidenced by the evolution of the hydraulic heads of is only perturbed by the episodic rain events. 
In the EMZ, the gradual decay caused by evaporation is damped even though the evaporation rate is the highest. This is because the mixing zone acts as a hydraulic barrier that isolates the two systems, the salt flat nucleus and the IMZ on one side and the main recharge area (mountains), the alluvial fans and the EMZ on the other, with the domains separated by the $M M Z$. In the EMZ, the rain events did not exhibit such a direct response in the water table, especially those far away from the intersection of the mixing zone with the land surface. The lateral groundwater recharge dominates the surface recharge, and the unsaturated zone becomes wider, weakening the direct effect of the rain. This process results in fairly constant hydraulic heads over time even though they are affected by evaporation and surface recharge (see the evolution of the hydraulic heads of the P2, P3 and P5 wells in Figure 8). As a consequence of the barrier effect exerted by the mixing zone, the hydrodynamics of the salt flat nucleus and the IMZ are those of pools that are quasi-isolated from the groundwater that arrives from the mountains as lateral recharge. The groundwater movement in these areas (nucleus and IMZ) is much slower and is controlled mainly by density-driven forces.

\subsection{ANTHROPOGENIC IMPACTS}

Under the natural regime, evaporation and recharge control the hydrodynamics and water table of the salt flat. However, in the Salar de Atacama there has been intensive brine exploitation, whose potential impacts on the natural hydrodynamics require analysis and quantification to extrapolate its behaviour to other salt flats.

\subsubsection{Water table evolution}

The water table evolution results from the numerical model shows the origin and evolution of different water table drawdowns as a consequence of the pumping of brine (Figures 7 and 8). Prior to 1994, the brine pumping performed in the southern area of the salt flat nucleus by ALB did not produce large disturbances in the natural regime. In 1994, the first effects of the pumping appeared, although they were still incipient and only located in the southern zone of the nucleus. In 2000, the affected area spread and more acute pumping depressions developed in the southern area. In addition, the effects of the reinjections in the central-western zone of the nucleus were also evident. This situation was accentuated in 2005 , when the southern water table drawdowns caused water heads lower than $2296 \mathrm{~m}$ a.s.I. In 2010, the southern drawdown cone continued to increase, and a new cone of depression was evident in the south-western sector. Both cones reached minimum hydraulic heads in 2015, with values below 2,292 m a.s.l. minimum hydraulic head, which moved from the eastern mixing zone or close to it to the 
501

southwestern salt flat nucleus (the main brine pumping area). However, the water heads in the mixing zone and outdoor areas remained practically constant throughout this period. This is the same as saying that until now, the salt flat nucleus has been the only one that has clearly suffered the effects of brine pumping. This may be explained by both the isolating effect of the mixing zone already described above and the important reduction of the evaporation rate in the nucleus caused by the drawdown of the water table. Indeed, as the evaporation rate from the groundwater is a function of the water table depth, the brine pumping causes an exponential decay in the evaporation rate, which results in a dampening of the water table. This effect of the water table is clearly evidenced in the piezometers P7 and P8 (Figure 8), which are located in the pumping area. The hydraulic heads of these piezometers clearly described the annual oscillations of evaporation during the pre-operation period, similar to the piezometers located far from the influence area of the pumping, but during the operational period, these oscillations disappeared as a consequence of the drawdown of the water table, indicating that evaporation process stopped as a result of the brine pumping. It is undeniable that the dependence of the evaporation rate on the water table depth enables any salt flat to counterbalance the increase and decrease of the entries of their basins. This makes salt flats and their ecosystems fairly stable over time on a geological scale, since wet periods with more rainfall would imply a rise in the water table that would automatically trigger an increase in the evaporation rate and therefore slow down this water table rise. In the same manner, a drier period would lead to inflows reduction in the basin due to rainfall, which would lead to a drawdown of the water table. The decrease in water table would cause a reduction in evaporation rate, which would slow down this water table drawdown. This effect is termed in the present work the damping capacity of the water table, which is a property of all salt flats that acts attenuating both natural and anthropogenic oscillations.

The damping capacity of the salt flats water table for natural oscillations is partially effective for anthropogenic perturbations of the basin water balance. However, to understand how the damping capacity responds to anthropogenic disturbances generated by brine pumping, it is necessary to delve into how the water balance has evolved at the basin scale during its transition. Thus, brine pumping beyond the natural evaporation outflow would cause irreversible depletions of the water heads until recharge was able to replace the pumped brine.

\subsubsection{Water balance evolution}

Therefore, it is necessary to analyse the water balance evolution computed by the 3D numerical model during the pre-operational and operational periods to advance the knowledge of the 
534 damping capacity of a salt flat when anthropogenic perturbations occur. First, the evolution of 535 each inflow and outflow of the basin during the natural and the anthropogenic regimes is shown 536 and discussed. Second, the effects of brine pumping in the water balance and the 537 counterbalance that the damping capacity has produced in water balance are evaluated.

538 In the case of Salar de Atacama, the system was dominated by a negative water balance, which 539 was counteracted punctually with rain events, especially during wet periods. The total inputs 540 along the modelled period were $1.39 \cdot 10^{10} \mathrm{~m}^{3}$, and the total outputs were $1.44 \cdot 10^{10} \mathrm{~m}^{3}$ (Figure 541 12). The resulting negative imbalance was $5.00 \cdot 10^{8} \mathrm{~m}^{3}$, which was less than the volume of 542 pumped brine.

\section{FIGURE 12}

544 As observed in the total water balance of the numerical model for the period from 1986-2015 545 (Figure 12), $89 \%$ of the inflows to the salt flat were produced through the deep lateral recharge 546 from the water infiltrated into the mountains. The remaining $11 \%$ comprised rainwater fallen 547 directly on the domain (7 \%), infiltration from streams (2 \%) and infiltration from the overflow 548 of the Soncor Lake system (2 \%).

549 The outflows of the system were produced by evaporation (95\%) and by extraction of brine (5 $550 \%)$. The Cauchy-type boundary condition exhibited adequate performance as the inflow 551 produced through this boundary condition was less than $5 \%$ of the outputs, and both remained 552 constant during the total modelled period.

553 The temporal evolution of the inflows, outflows and storage over time is shown in Figure 13. 554 The annual inflows oscillated between $13.54 \mathrm{~m}^{3} \cdot \mathrm{s}^{-1}$ and $17.31 \mathrm{~m}^{3} \cdot \mathrm{s}^{-1}$, whereas the outflows had 555 a lower oscillation range, between $14.46 \mathrm{~m}^{3} \cdot \mathrm{s}^{-1}$ and $15.82 \mathrm{~m}^{3} \cdot \mathrm{s}^{-1}$. The inflows to the system were 556 mainly represented by the rainwater recharge, which depends on the climate cycles. This results 557 in inflow oscillations over time. On the other hand, the evaporation depends on the potential 558 evaporation, which may be considered similar every year (taking into account interannual 559 variability), and on the water table depth, which decreased throughout the modelled period but 560 was countered by the brine pumping (Figure 13B). Consequently, the outflows of the system 561 exhibit lower oscillation amplitudes than the inflows.

\section{FIGURE 13}

In the Salar de Atacama, the natural water balance was modified by the beginning of the brine exploitation. From then on, a new negative component was added to the water balance of the system. However, there is no linear relationship between the water pumped and the decrease 
in storage. This behaviour is associated with the damping capacity of salt flats. When a certain

567 volume of brine is extracted, a drawdown in the water table is generated, which causes a 568 reduction in the evaporation rate due to an increase in the thickness of the unsaturated zone. 569 Therefore, an increase in the brine pumping rate implies a decrease in the evaporation rate, 570 counteracting, in part, the effect of brine pumping on the total water balance (Figure 13B).

571 Although the drawdown of the water table may favour the influx of water from the side of the 572 salt flat or from the depth, which are difficult to assess, the main factor responsible for the 573 damping capacity is the modification of the evaporation rate. From an ecological point of view 574 this damping effect may reduce the impacts of the mixing zone on lake and wetland ecosystems. 575 However, it must be considered that the damping capacity is limited to the movement of the 576 water table at depths shallower than $2 \mathrm{~m}$. Below this depth, the evaporation rate goes to zero, 577 and the damping capacity is lost.

578 The biggest contributor to the damping capacity of the salt flat water table is the nucleus, at 579 least when the natural or anthropic disturbances are small or moderate. This is due to two 580 reasons: (1) the large extent of the nucleus and (2) the location of the brine pumping wells. The 581 nucleus of the salt flats generally has a large extent, which implies that even though the 582 evaporation rate is much lower than that of the mixing zone, a small rise or fall of the water 583 table leads to a significant change within the total water balance. This is applicable for both 584 natural and anthropogenic disturbances. In addition, because the brines are more evaporated 585 and therefore have a higher economic value in the salt flat nucleus, the brine pumping wells are 586 located in that sector. Due to brine pumping, the nucleus suffers the greatest impact in terms of 587 hydraulic heads and consequently evaporation rates.

\section{5. CONCLUSIONS}

589 The coupled natural and anthropogenic processes that control the hydrodynamics of many salt 590 flats were addressed using the Salar de Atacama as a case study. A three-dimensional 591 groundwater flow model was used to reproduce the water table evolution of the Salar de 592 Atacama from 1986 to 2015. This also permitted quantifying the water balance impacts. The three-dimensional approach for the modelling of the groundwater flow in salt flats was demonstrated to be a power tool to evaluate natural processes and anthropogenic impacts and to be of great utility for the management of these systems. period (1986-1994). In the natural regime, the water table exhibited a gradual drawdown because the evaporation was greater than the recharge most of the time. This negative balance 

was counteracted by some sharp rises produced by direct rainfall events on the salt flat. The lateral recharge that arrived from the mountains did not produce abrupt perturbations to the water table because the rainfall events in the mountains were damped by the distance from the recharge zone and the great thickness of the unsaturated zone.

The natural regime of the water table was disturbed by the brine pumping performed in the Salar de Atacama during the operational period (1994-2015). The pumping causes a fall in the water table, which results in a decrease of the evaporation rate that at least partially compensates for the pumped brine. This effect is termed in the present work the damping capacity of the salt flats. Due to this process, salt flats have a capacity for damping their water tables in response to both natural and anthropogenic disturbances, which is of great importance for the management of lake and wetland ecosystems and brine mining. The limit of the damping capacity of salt flats is defined by the evaporation extinction depth, which is between 0.5 and 2 $\mathrm{m}$.

\section{ACKNOWLEDGMENTS}

The authors acknowledge Sociedad Química y Minera de Chile S.A. for their support and sharing data throughout the hydrogeological characterization of the SdA site. M.A. Marazuela gratefully acknowledges the financial support from the AGAUR (Agència de Gestió d'Ajuts Universitaris I de Recerca, Generalitat de Catalunya) and the European Union (grant number 2018FI B2 00068). Finally, we thank four anonymous reviewers for their valuable comments.

8

9

0

1

22

(1)

4

25


Acosta, O., Custodio, E., 2008. Impactos ambientales de las extracciones de agua subterranea en el Salar del Huasco (norte de Chile). Bol. Geol. y Min. 119, 33-50.

Arriagada, C., Cobbold, P.R., Roperch, P., 2006. Salar de Atacama basin: A record of compressional tectonics in the central Andes since the mid-Cretaceous. Tectonics 25, TC1008. doi:10.1029/2004TC001770

Bakalowicz, M., 2005. Karst groundwater: A challenge for new resources. Hydrogeol. J. 13, 148-160. doi:10.1007/s10040-004-0402-9

Bookhagen, B., Strecker, M.R., 2008. Orographic barriers, high-resolution TRMM rainfall, and relief variations along the eastern Andes. Geophys. Res. Lett. 35, L06403. doi:10.1029/2007GL032011

Boutt, D.F., Hynek, S.A., Munk, L.A., Corenthal, L.G., 2016. Rapid recharge of fresh water to the halite-hosted brine aquifer of Salar de Atacama, Chile. Hydrol. Process. 30, 4720-4740. doi:10.1002/hyp.10994

Bowen, B.B., Kipnis, E.L., Raming, L.W., 2017. Temporal dynamics of flooding, evaporation, and desiccation cycles and observations of salt crust area change at the Bonneville Salt Flats, Utah. Geomorphology 299, 1-11. doi:10.1016/j.geomorph.2017.09.036

Comisión Regional del Medio Ambiente, 2006. Resolución de Calificación Ambiental No226/2006. Antofagasta, Chile.

Corenthal, L.G., Boutt, D.F., Hynek, S.A., Munk, L.A., 2016. Regional groundwater flow and accumulation of a massive evaporite deposit at the margin of the Chilean Altiplano. Geophys. Res. Lett. 43, 8017-8025. doi:10.1002/2016GL070076

Cornellà, O., Salas, J., Aravena, R., Guzmán, E., Guimerà, J., Tore, C., Von Igel, W., Henríquez, A., Fock, A., 2009. Hidrogeologia de los sistemas lagunares del margen E del Salar de Atacama, in: XII Congreso Geológico Chileno. Santiago de Chile, pp. 1-4.

Diersch, H.-J.G., 2014. FEFLOW: Finite Element Modeling of Flow, Mass and Heat Transport in Porous and Fractured Media. doi:10.1007/978-3-642-38739-5

Doherty, J., 2015. Calibration and Uncertainty Analysis for Complex Environmental Models. Groundwater 56, 673-674.

Duffy, C.J., Al-Hassan, S., 1988. Groundwater circulation in a closed desert basin: Topographic 

scaling and climatic forcing. Water Resour. Res. 24, 1675-1688. doi:10.1029/WR024i010p01675

Evans, R.K., 1978. Lithium reserves and resoruces. Energy 3, 379-385.

Fan, Y., Duffy, C.J., Oliver, D.S., 1997. Density-driven groundwater flow in closed desert basins: Field investigations and numerical experiments. J. Hydrol. 196, 139-184. doi:10.1016/S0022-1694(96)03292-1

Hamann, E., Post, V., Kohfahl, C., Prommer, H., Simmons, C.T., 2015. Numerical investigation of coupled density-driven flow and hydrogeochemical processes below playas. Water Resour. Res. 51, 9338-9352. doi:10.1002/2015WR017833

Hardie, L.A., 1991. On the significance of evaporites. Annu. Rev. Earth Planet. Sci. 19, 131-68.

Holzbecher, E., 2005. Groundwater flow pattern in the vicinity of a salt lake. Hydrobiologia $532,233-242$.

Houston, J., 2006. Variability of precipitation in the Atacama Desert: Its causes and hydrological impact. Int. J. Climatol. 26, 2181-2198. doi:10.1002/joc.1359

IDAEA-CSIC, 2017. Cuarta actualización del modelo hidrogeológico del Salar de Atacama. Santiago, Chile.

Kampf, S.K., Tyler, S.W., 2006. Spatial characterization of land surface energy fluxes and uncertainty estimation at the Salar de Atacama, Northern Chile. Adv. Water Resour. 29, 336-354. doi:10.1016/j.advwatres.2005.02.017

Kampf, S.K., Tyler, S.W., Ortiz, C.A., Muñoz, J.F., Adkins, P.L., 2005. Evaporation and land surface energy budget at the Salar de Atacama, Northern Chile. J. Hydrol. 310, 236-252. doi:10.1016/j.jhydrol.2005.01.005

Karl, T.R., Williams, C.N., 1987. An approach to adjusting Climatological Time Series for Discontinuous Inhomogeneities. J. Clim. Appl. Meteorol. 26, 1744-1762. doi:10.1175/1520-0450(1987)026<1744:AATACT>2.0.CO;2

Kesler, S.E., Gruber, P.W., Medina, P.A., Keoleian, G.A., Everson, M.P., Wallington, T.J., 2012. Global lithium resources: Relative importance of pegmatite, brine and other deposits. Ore Geol. Rev. 48, 55-69. doi:10.1016/j.oregeorev.2012.05.006

Lowenstein, T.K., Risacher, F., 2009. Closed basin brine evolution and the influence of Ca-Cl inflow waters: Death valley and bristol dry lake California, Qaidam Basin, China, and Salar 
689

690

691

692

693

694

695

696

697

698

699

700

701

702

703

704

705

706

707

708

709

710

711

712

713

714

Marazuela, M.A., Vázquez-Suñé, E., Ayora, C., García-Gil, A., Palma, T., 2019. Hydrodynamics of salt flat basins: The Salar de Atacama example. Sci. Total Environ. 651, 668-683. doi:10.1016/j.scitotenv.2018.09.190

Marazuela, M.A., Vázquez-Suñé, E., Custodio, E., Palma, T., García-Gil, A., Ayora, C., 2018. 3D mapping, hydrodynamics and modelling of the freshwater-brine mixing zone in salt flats similar to the Salar de Atacama (Chile). J. Hydrol. 561, 223-235. doi:10.1016/j.jhydrol.2018.04.010

Marom, R., Amalraj, S.F., Leifer, N., Jacob, D., Aurbach, D., 2011. A review of advanced and practical lithium battery materials. J. Mater. Chem. 21, 9938-9954. doi:10.1039/c0jm04225k

Mpodozis, C., Arriagada, C., Basso, M., Roperch, P., Cobbold, P., Reich, M., 2005. Late Mesozoic to Paleogene stratigraphy of the Salar de Atacama Basin, Antofagasta, Northern Chile: Implications for the tectonic evolution of the Central Andes. Tectonophysics 399, 125154. doi:10.1016/j.tecto.2004.12.019

Munk, L.A., Hynek, S.A., Bradley, D., Boutt, D.F., Labay, K., Jochens, H., 2016. Lithium brines: A global perspective. Rev. Econ. Geol. 18, 339-365.

Muñoz-Pardo, J.F., Ortiz-Astete, C.A., Mardones-Pérez, L., de Vidts-Sabelle, P., 2004. Funcionamiento hidrogeológico del acuífero del núcleo del salar de Atacama, Chile. Ing. Hidráulica en Mex. XIX, 69-81.

Muñoz, N., Charrier, R., Jordan, T., 2002. Interactions between basement and cover during the evolution of the Salar de Atacama Basin, northern Chile. Rev. geológica Chile 29, 3-29. doi:10.4067/S0716-02082002000100004

Nield, D.A., Simmons, C.T., Kuznetsov, A. V., Ward, J.D., 2008. On the evolution of salt lakes: Episodic convection beneath an evaporating salt lake. Water Resour. Res. 44, W02439. doi:10.1029/2007WR006161

Ortiz, C., Aravena, R., Briones, E., Suárez, F., Tore, C., Muñoz, J.F., 2014. Sources of surface water for the Soncor ecosystem, Salar de Atacama basin, northern Chile. Hydrol. Sci. J. 59, 336-350. doi:10.1080/02626667.2013.829231

Pananont, P., Mpodozis, C., Blanco, N., Jordan, T.E., Brown, L.D., 2004. Cenozoic evolution of the northwestern Salar de Atacama Basin, northern Chile. Tectonics 23, 1-19. 
doi:10.1029/2003TC001595

720

721

722

Peterson, T.C., Easterling, D.R., 1994. Creation of homogeneous composite climatological reference series. Int. J. Climatol. 14, 671-679. doi:10.1002/joc.3370140606

Philip, J.R., 1957. Evaporation, and moisture and heat fields in the soil. J. Meteorol. 14, 354366. doi:10.1175/1520-0469(1957)014<0354:EAMAHF>2.0.CO;2

Rech, J.A., Currie, B.S., Michalski, G., Cowan, A.M., 2006. Neogene climate change and uplift in the Atacama Desert, Chile. Geology. doi:10.1130/G22444.1

Risacher, F., Alonso, H., Salazar, C., 2003. The origin of brines and salts in Chilean salars: A hydrochemical review. Earth-Science Rev. 63, 249-293. doi:10.1016/S00128252(03)00037-0

Rissmann, C., Leybourne, M., Benn, C., Christenson, B., 2015. The origin of solutes within the groundwaters of a high Andean aquifer. Chem. Geol. 396, 164-181. doi:10.1016/j.chemgeo.2014.11.029

Rockwood-Lithium, 2015. Estudio Hidrogeológico y Modelo Numérico Sector Sur del Salar de Atacama (Anexo 1). Para Estudio de Impacto Ambiental Proyecto Modificaciones y Mejoramiento del Sistema de Pozas de Evaporación solar en el Salar de Atacama. Santiago, Chile.

Rosen, M.R., 1994. The importance of groundwater in playas: A review of playa classifications and the sedimentology and hydrology of playas. Geol. Soc. Am. Spec. Pap. 289, 1-18. doi:10.1130/SPE289-p1

Salas, J., Guimerà, J., Cornellà, O., Aravena, R., Guzmán, E., Tore, C., Von Igel, W., Moreno, R., 2010. Hidrogeologia del sistema lagunar del margen este del Salar de Atacama (Chile). Bol. Geol. y Min. 121, 357-372.

Scanlon, B.R., Mace, R.E., Barrett, M.E., Smith, B., 2003. Can we simulate regional groundwater flow in a karst system using equivalent porous media models? Case study, Barton Springs Edwards aquifer, USA. J. Hydrol. 276, 137-158. doi:10.1016/S0022-1694(03)00064-7

Tejeda, I., Cienfuegos, R., Muñoz, J.F., Durán, M., 2003. Numerical Modeling of Saline Intrusion in Salar de Atacama. J. Hydrol. Eng. 8, 25-34. doi:10.1061/(ASCE)1084-0699(2003)8:1(25)

Tyler, S.W., Muñoz, J.F., Wood, W.W., 2006. The response of playa and sabkha hydraulics and mineralogy to climate forcing. GroundwaterWater 44, 329-338. doi:10.1111/j.1745- 
750 Vásquez, C., Ortiz, C., Suárez, F., Muñoz, J.F., 2013. Modeling flow and reactive transport to explain mineral zoning in the Atacama salt flat aquifer, Chile. J. Hydrol. 490, 114-125. doi:10.1016/j.jhydrol.2013.03.028

753

765

766

767

768

769

770

771

772

773

774

775

\section{1}

Vikström, H., Davidsson, S., Höök, M., 2013. Lithium availability and future production outlooks. Appl. Energy 110, 252-266. doi:10.1016/j.apenergy.2013.04.005

Warren, J.K., 2010. Evaporites through time: Tectonic, climatic and eustatic controls in marine and nonmarine deposits. Earth-Science Rev. 98, 217-268. doi:10.1016/j.earscirev.2009.11.004

Wood, W.W., Sanford, W.E., 1990. Ground-water control of evaporite deposition. Econ. Geol. 85, 1226-1235. doi:10.2113/gsecongeo.85.6.1226

Wooding, R.A., Tyler, S.W., White, I., 1997. Convection in groundwater below an evaporating Salt Lake: 1. Onset of instability. Water Resour. Res. 33, 1199-1217. doi:10.1029/96WR03533

Yechieli, Y., Wood, W.W., 2002. Hydrogeologic processes in saline systems: Playas, sabkhas, and saline lakes. Earth-Science Rev. 58, 343-365. doi:10.1016/S0012-8252(02)00067-3

\section{5}

66

67

68

\section{(1)}

770

2

, 
777

FIGURE 1: Location of the Salar de Atacama (LANDSAT 8: 27 September, 2016). The black lines border the salt flat nucleus and the mixing zone. The three sub-zones of the mixing zone are shown in orange lettering (internal, IMZ; middle, MMZ and external, EMZ).

FIGURE 2: Hydrogeological performance of the Salar de Atacama basin (modified from Marazuela et al., 2019). Q is the Quelana Lake, SLS is the Soncor Lake system, Tb is the Tebenquiche Lake and SP is the San Pedro alluvial fan.

FIGURE 3: Superficial recharge and evaporation zones (modified from Marazuela et al., 2019). A) Regional recharge sub-basins and isohyets map. Green points indicate the positions of the weather stations. The basin recharge values of each zone are listed in Table S1. B) Recharge zones at the surface of the model domain. The recharge and evaporation values of each zone are listed in Table S2.

FIGURE 4: Zoning of the hydraulic conductivity (A) and specific storage (B) for each hydrogeological unit (modified from Marazuela et al., 2019). The hydraulic conductivity values are listed in Table S4 and the specific storage values in Table S5.

FIGURE 5: Mesh of the 3D numerical model. A) 3D view. B) East-West vertical cross section. C) North-South vertical cross section.

FIGURE 6: Methodology used for the definition of the equivalent wells.

FIGURE 7: Hydraulic head contour maps resulting from the 3D transient-state numerical model. The results are shown every five-year periods from December 31 $1^{\text {st }}, 1990$ to December $31^{\text {st }}, 2015$. The black letters indicate the value of each hydraulic head contour line in meters above sea level (m a.s.l.).

FIGURE 8: Hydraulic head evolution at eleven observational wells showing the modelled versus measured (observed) data. The measured data outside the mixing zone were corrected for density variations following the methodology of Marazuela et al. (2018). The location of the piezometers are shown in the centre of the figure.

FIGURE 9: Experimental data of evaporation rates taken by lysimeters located in the evaporation zones A3 and A7. The fit of the average exponential curve was based on the Philip (1957) type curve.

FIGURE 10: Correlation between hydraulic head data from observational wells W1, W2 and W3 (see its location in Figure 1) and the normalized evapotranspiration function. 
807 FIGURE 11: Correlation between rain events registered at three weather stations (WS8, WS9 808 and WS10) (see its location in Figure 3A) and the hydraulic head values of the observational wells 809 W4 and W5 (see its location in Figure 1).

810 FIGURE 12: Total water balance resulting from the 3D transient-state numerical model.

811 FIGURE 13: Water balance evolution. Continuous lines correspond to the primary vertical axis 812 and dashed lines correspond to the secondary vertical axis. A) Total inputs, outputs and storage 813 rates. B) Total evaporation and pumping rates.

814

815

816

817

818

819

820

821

822

823

824

825

826

827

828

829

830

831

832 


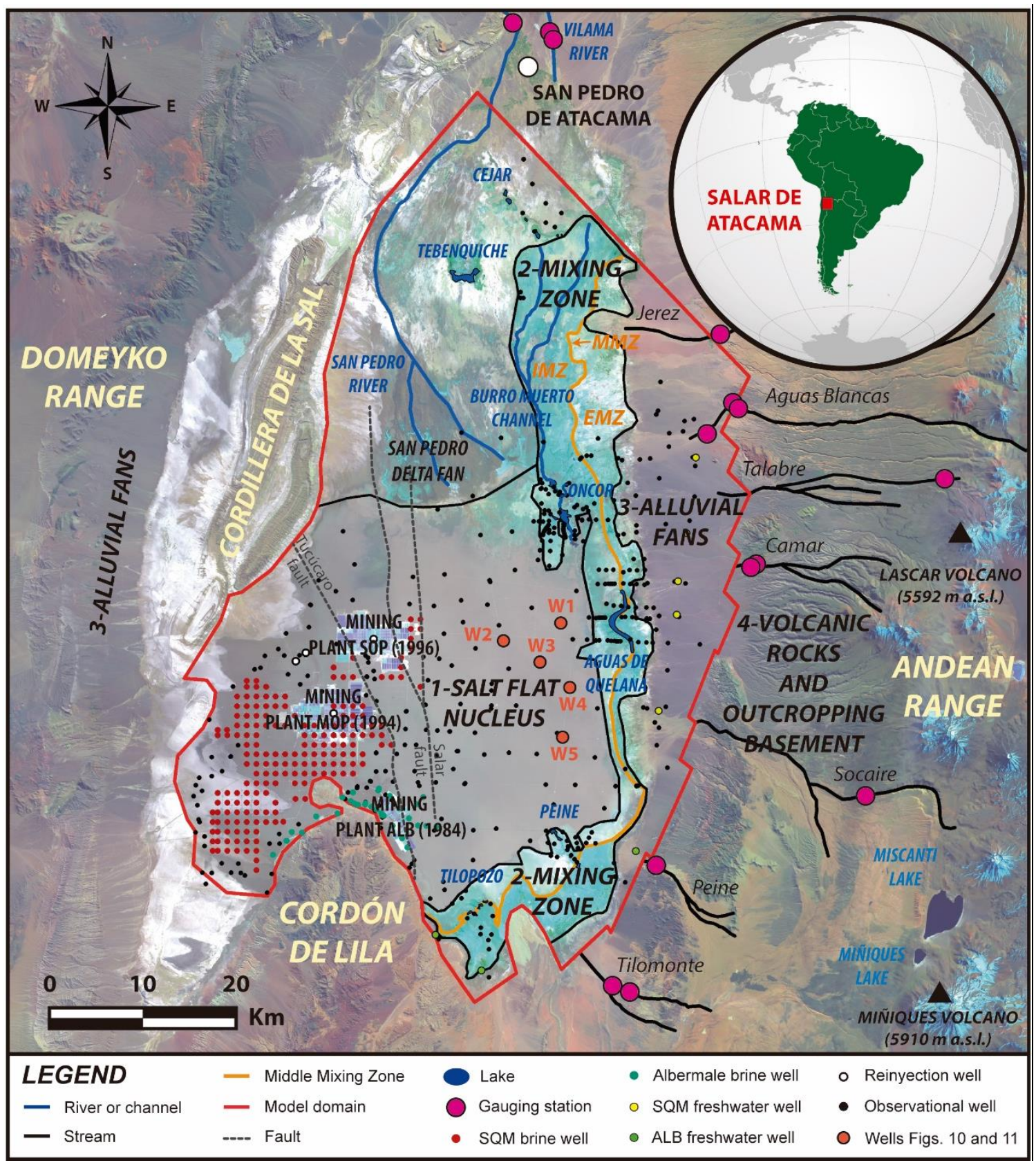




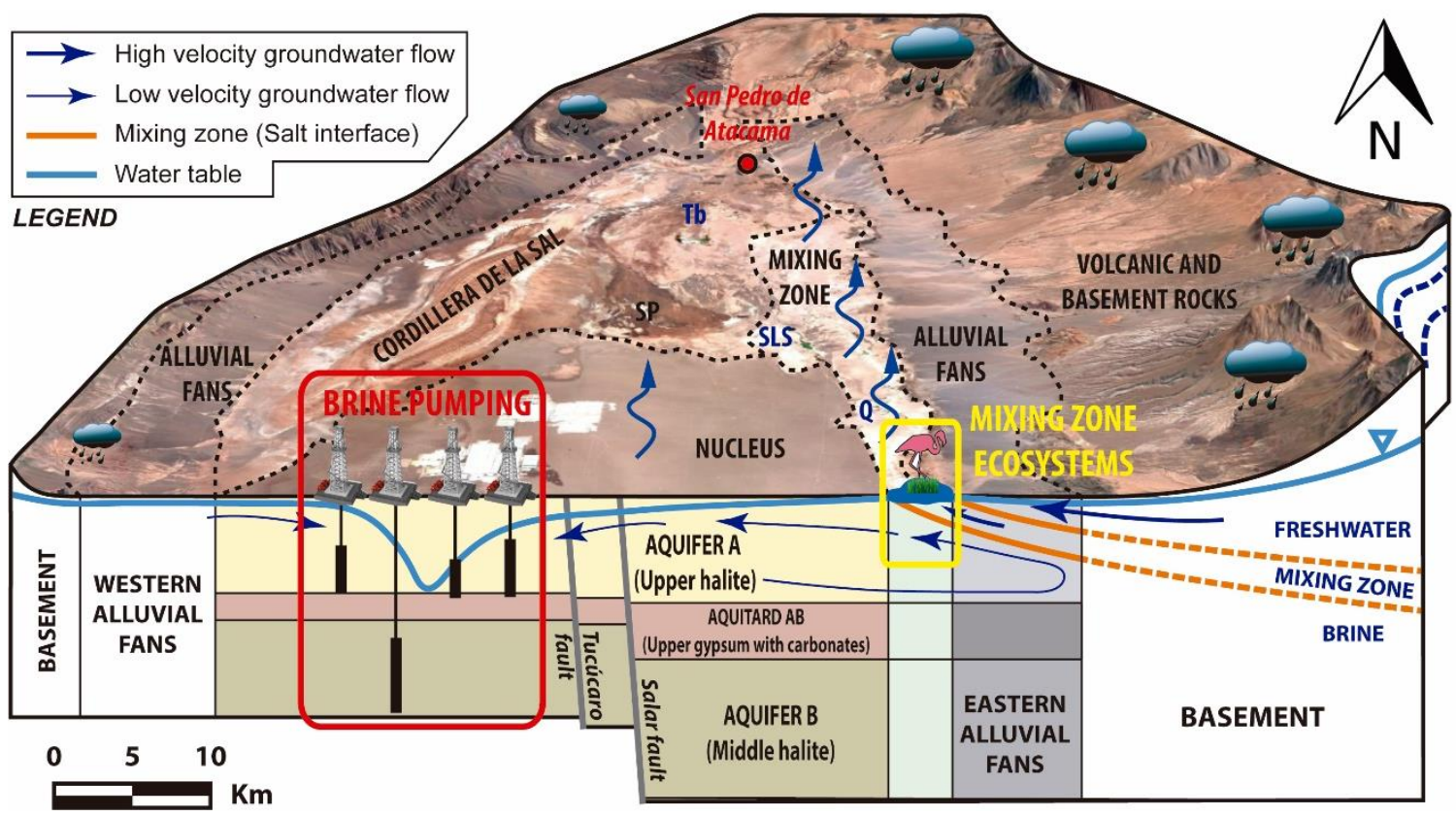




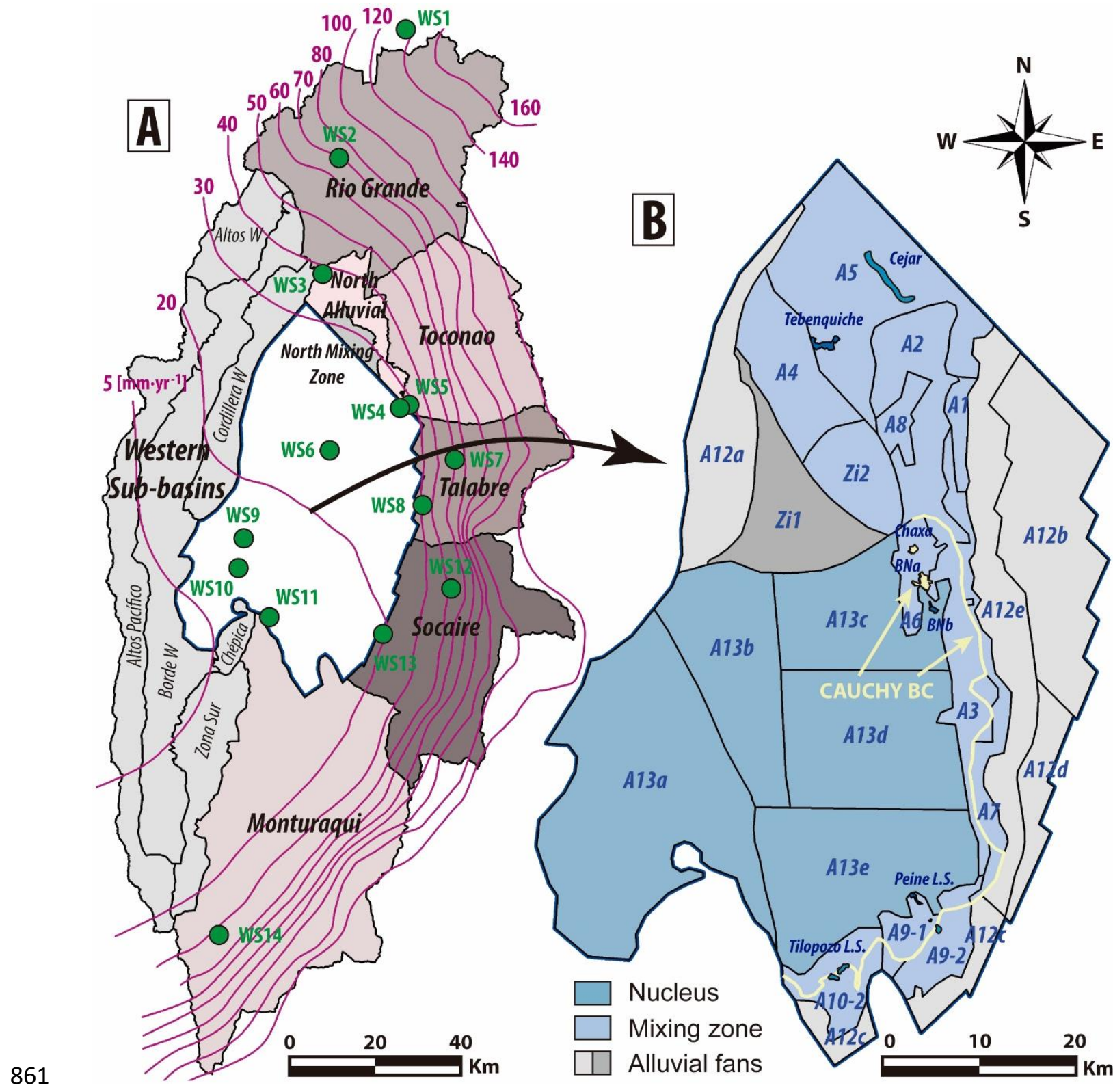

862 

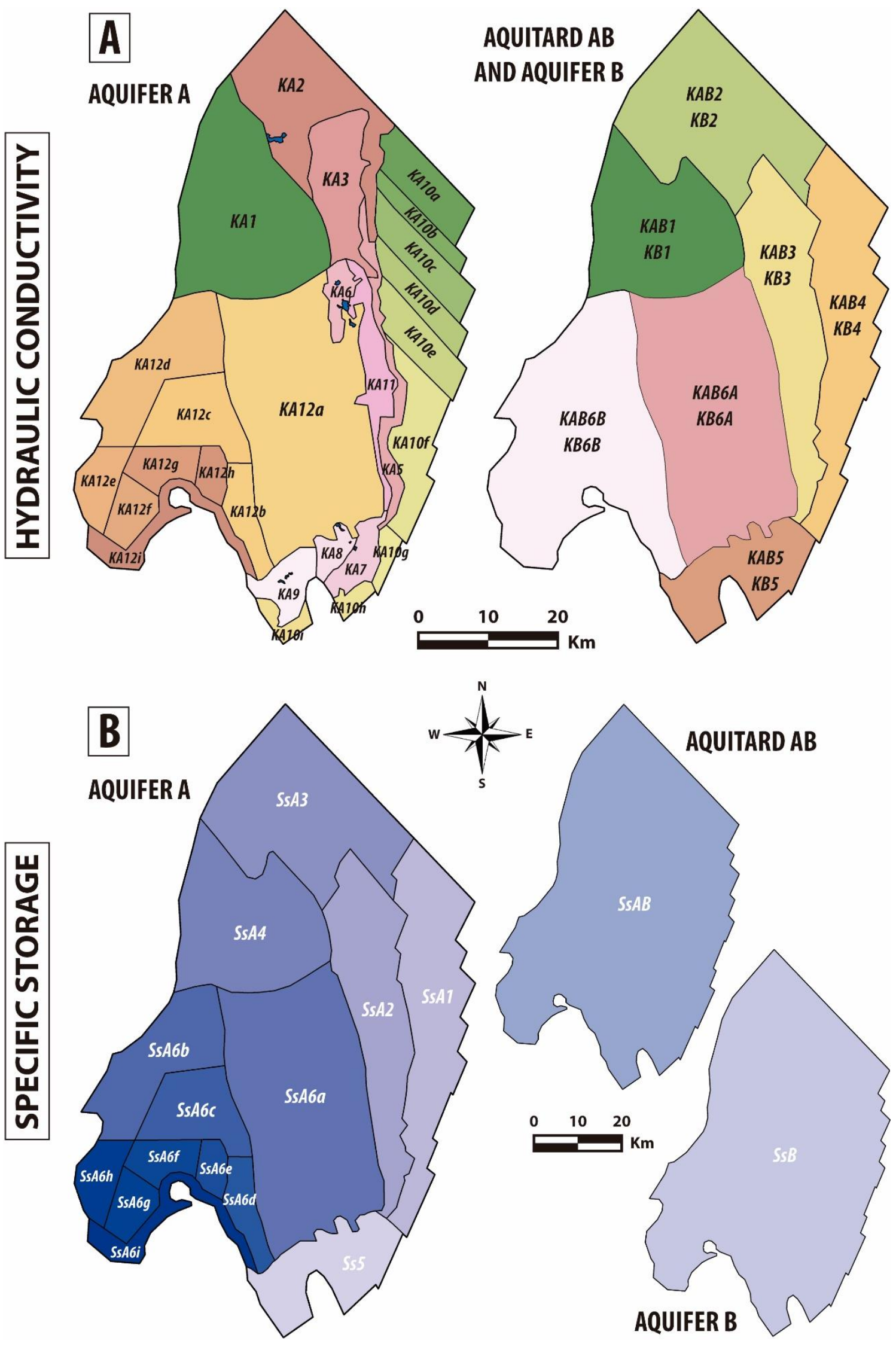

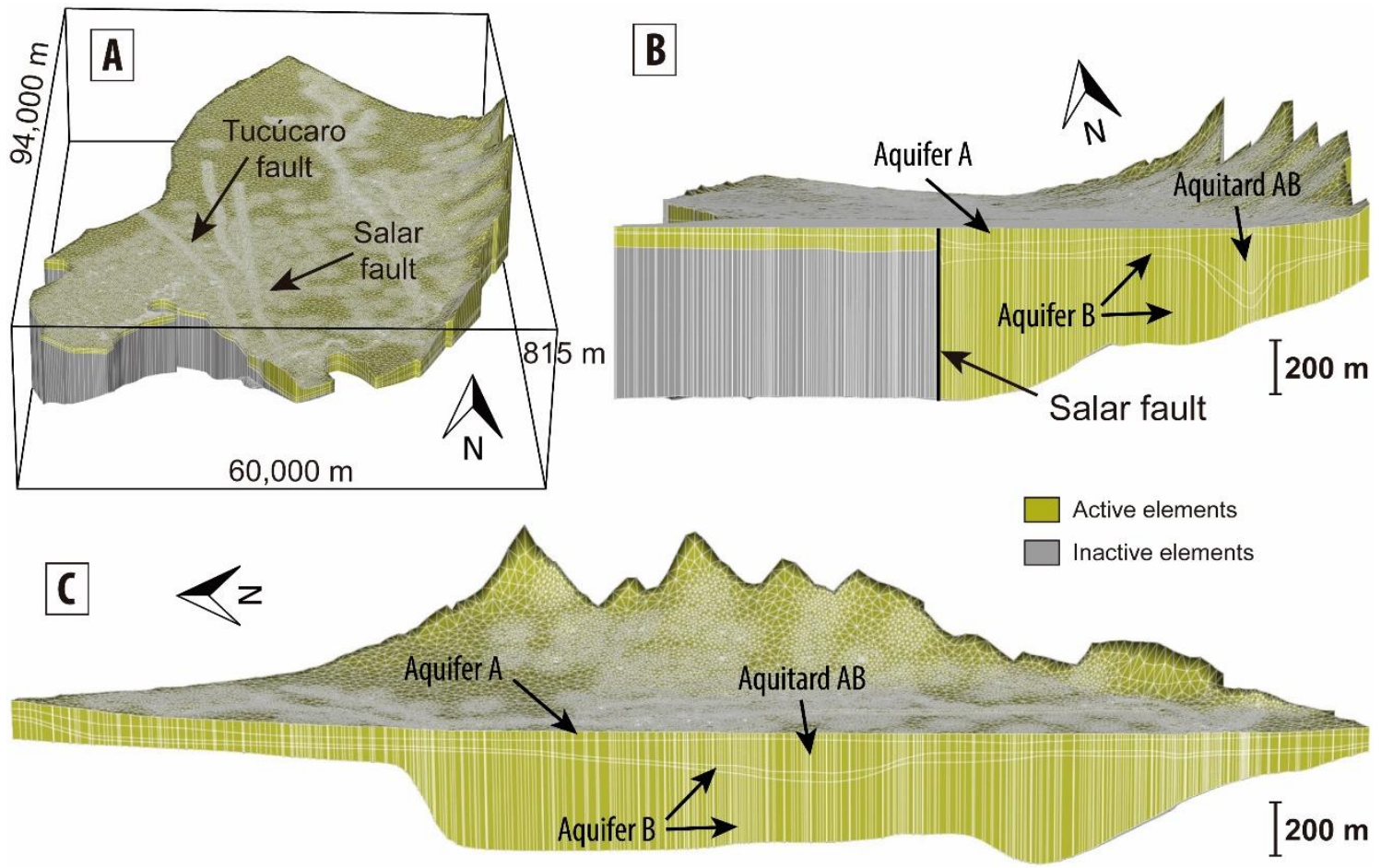

874

875

876

877

878

879

880

881

882

883

884

885

886

887 


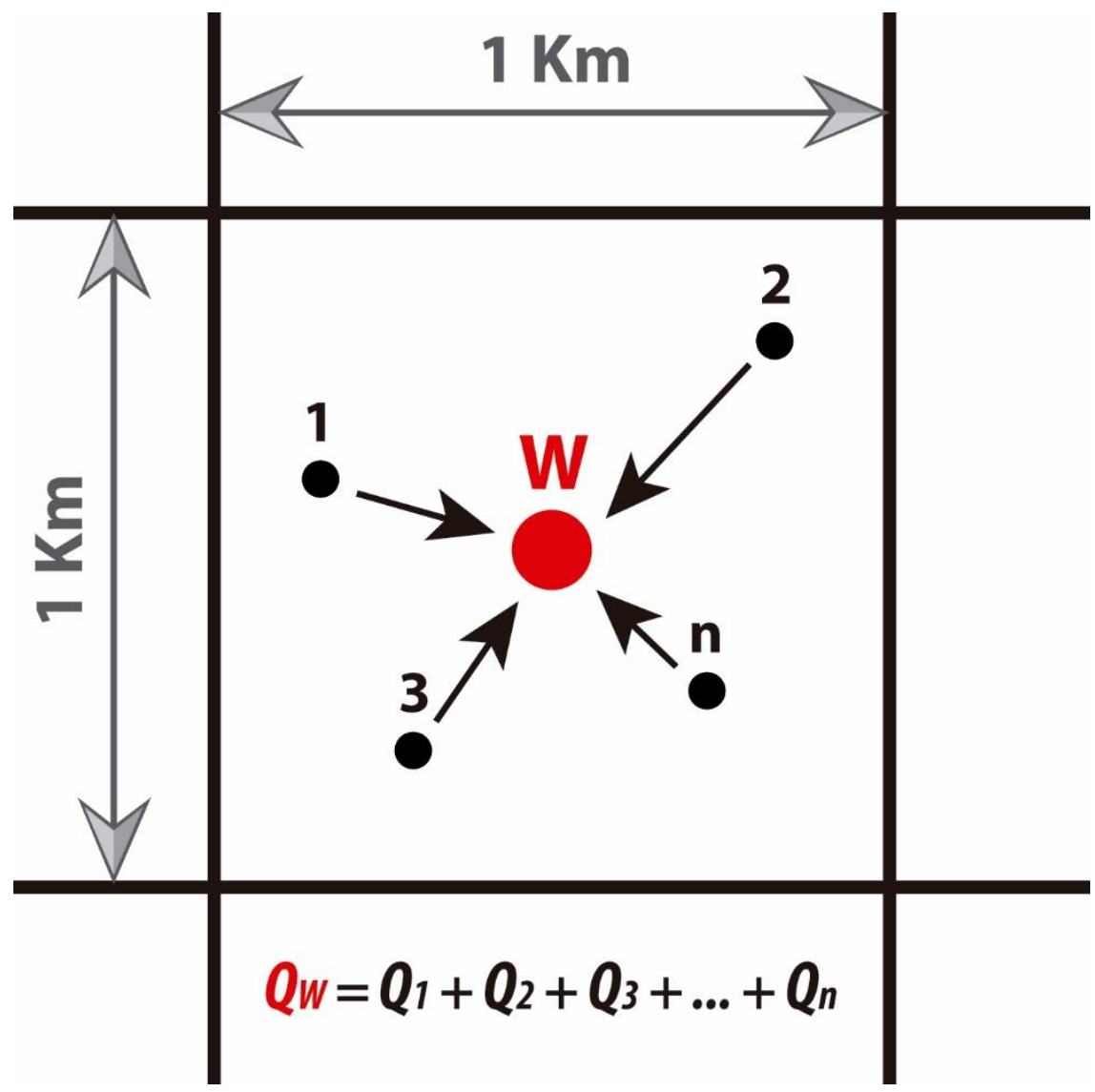

890 


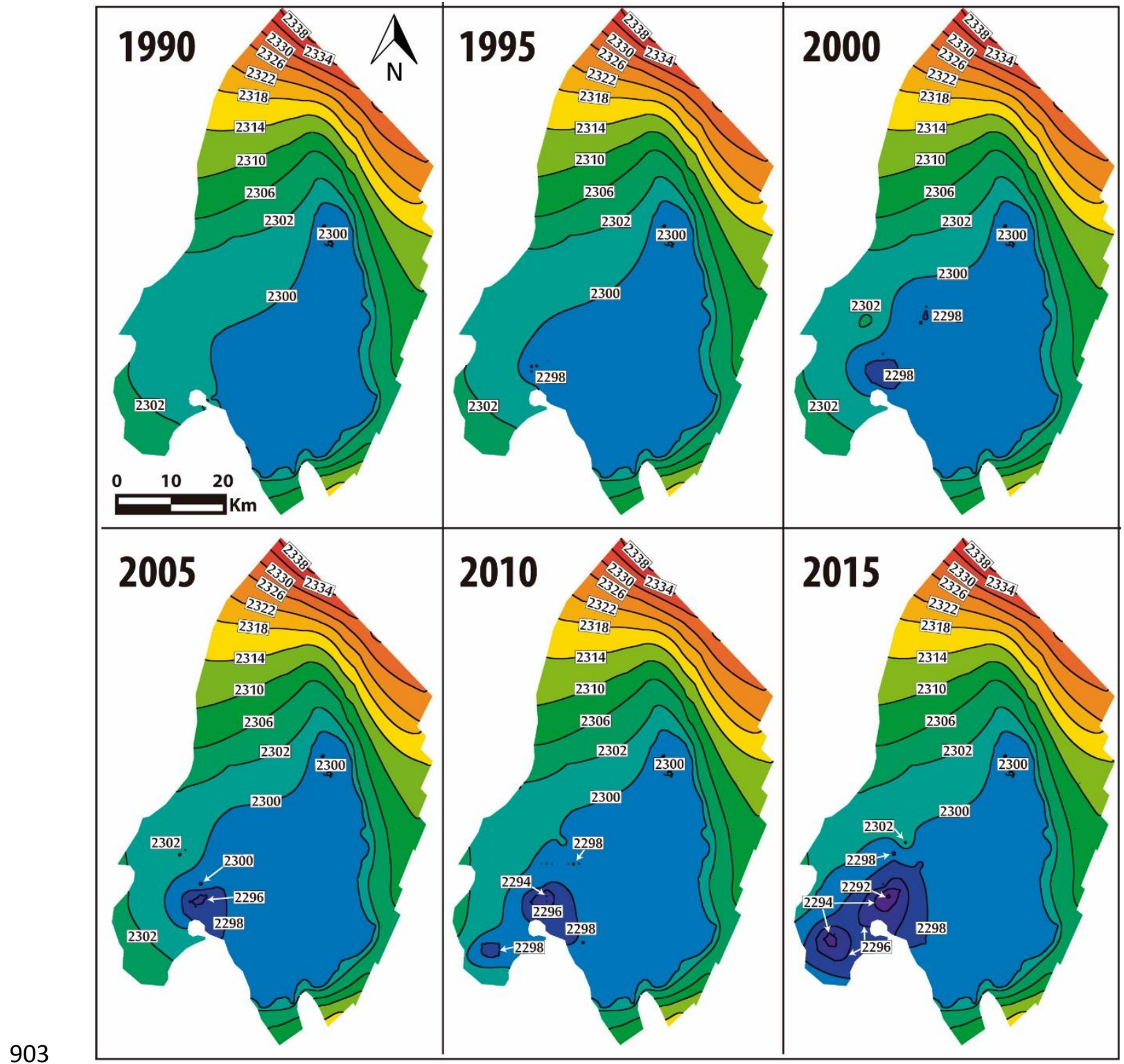

904

905

906

907

908

909

910

911 

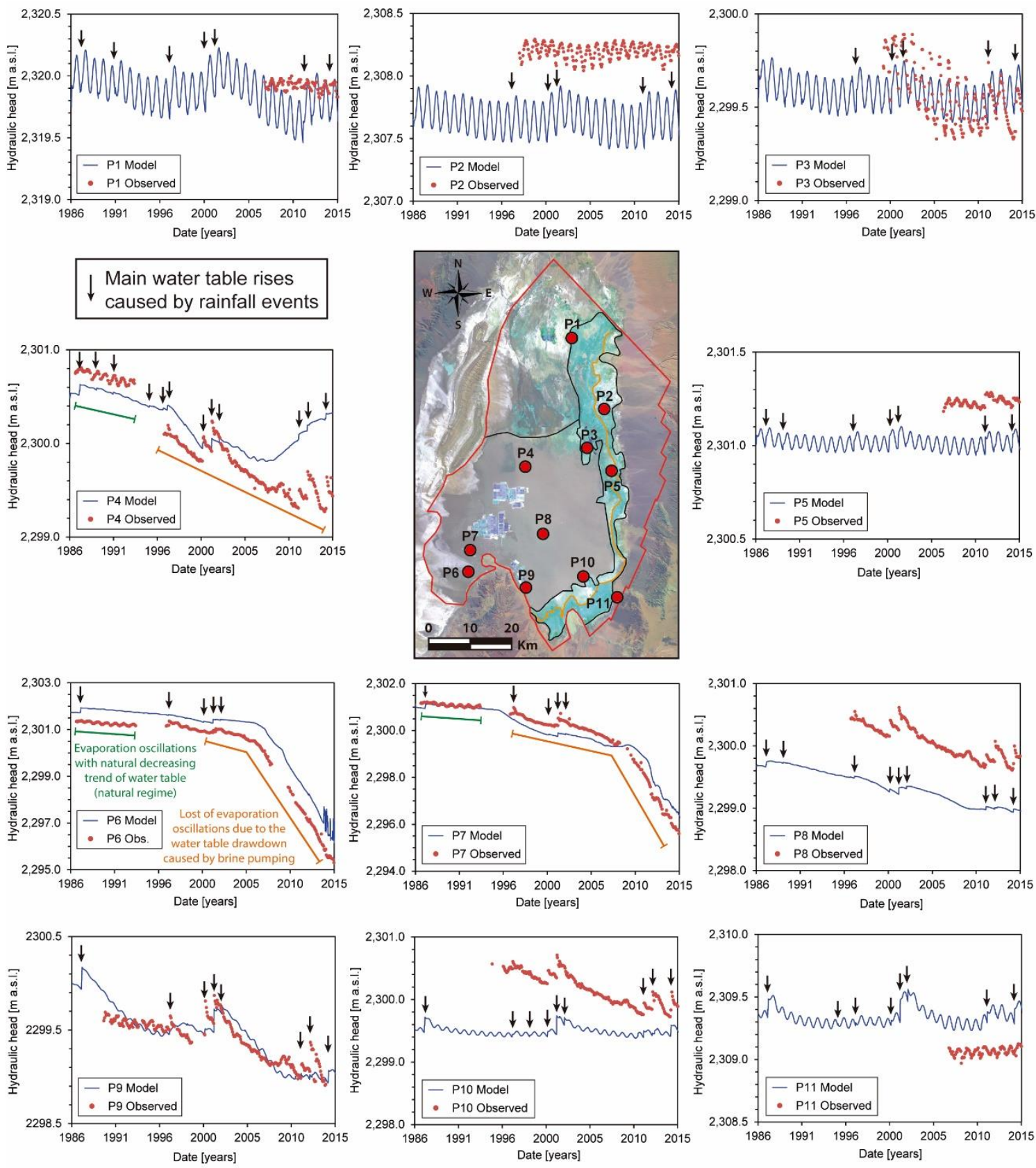

913 


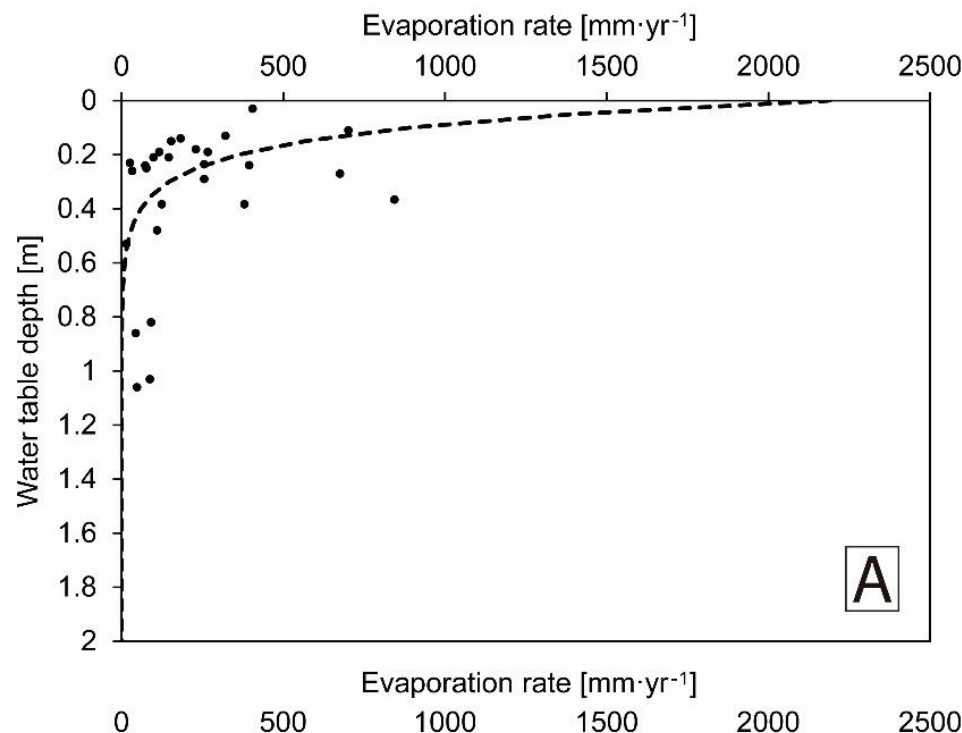

921

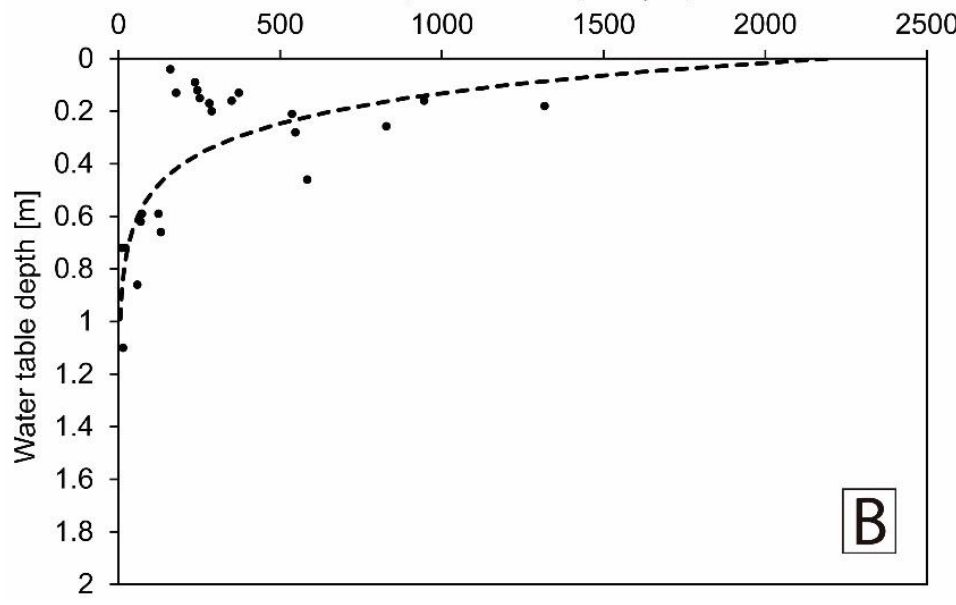

922

923

924

925

926

927

928

929

930

931 


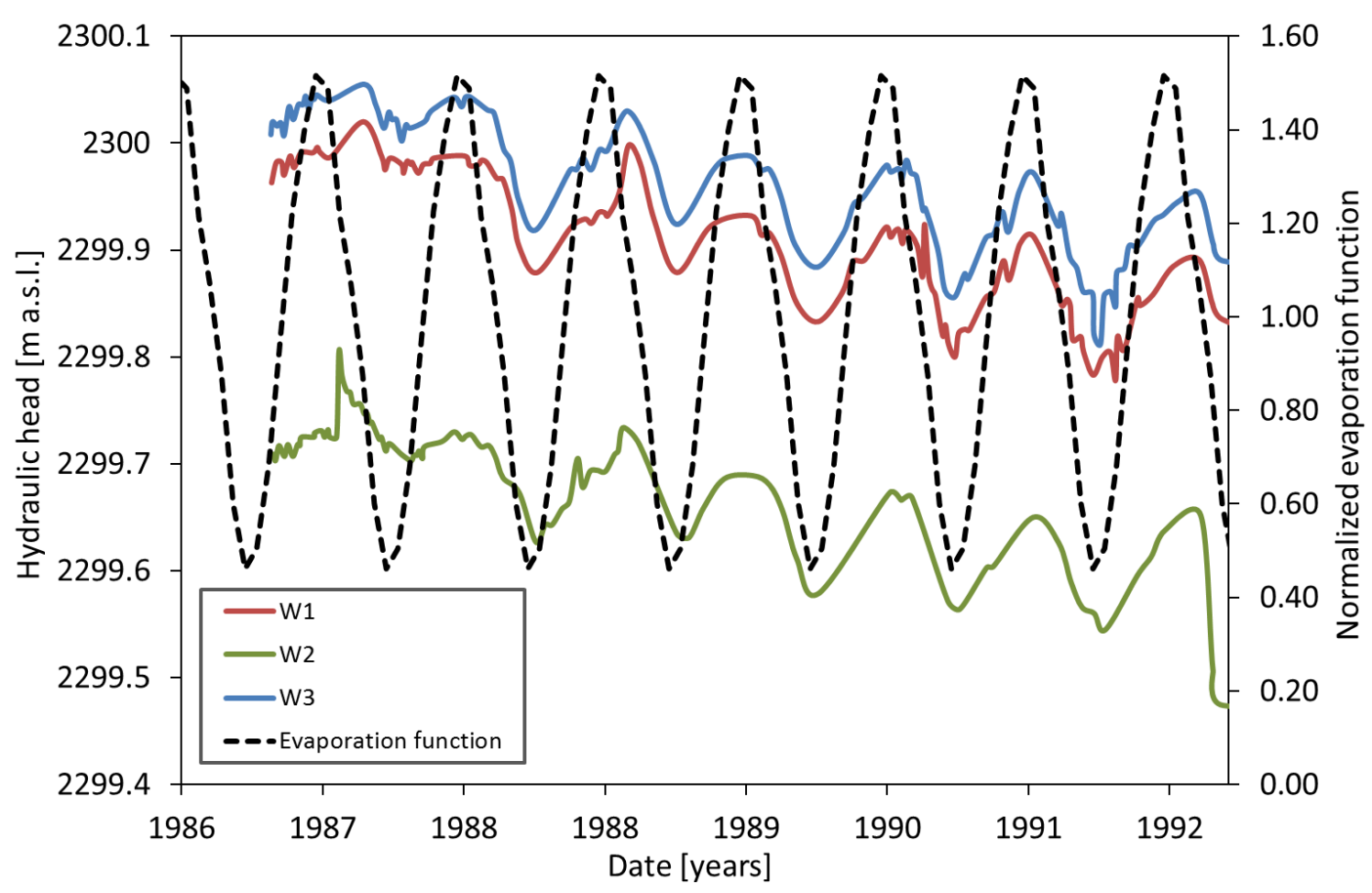

934

935

936

937

938

939

940

941

942

943

944

945

946 


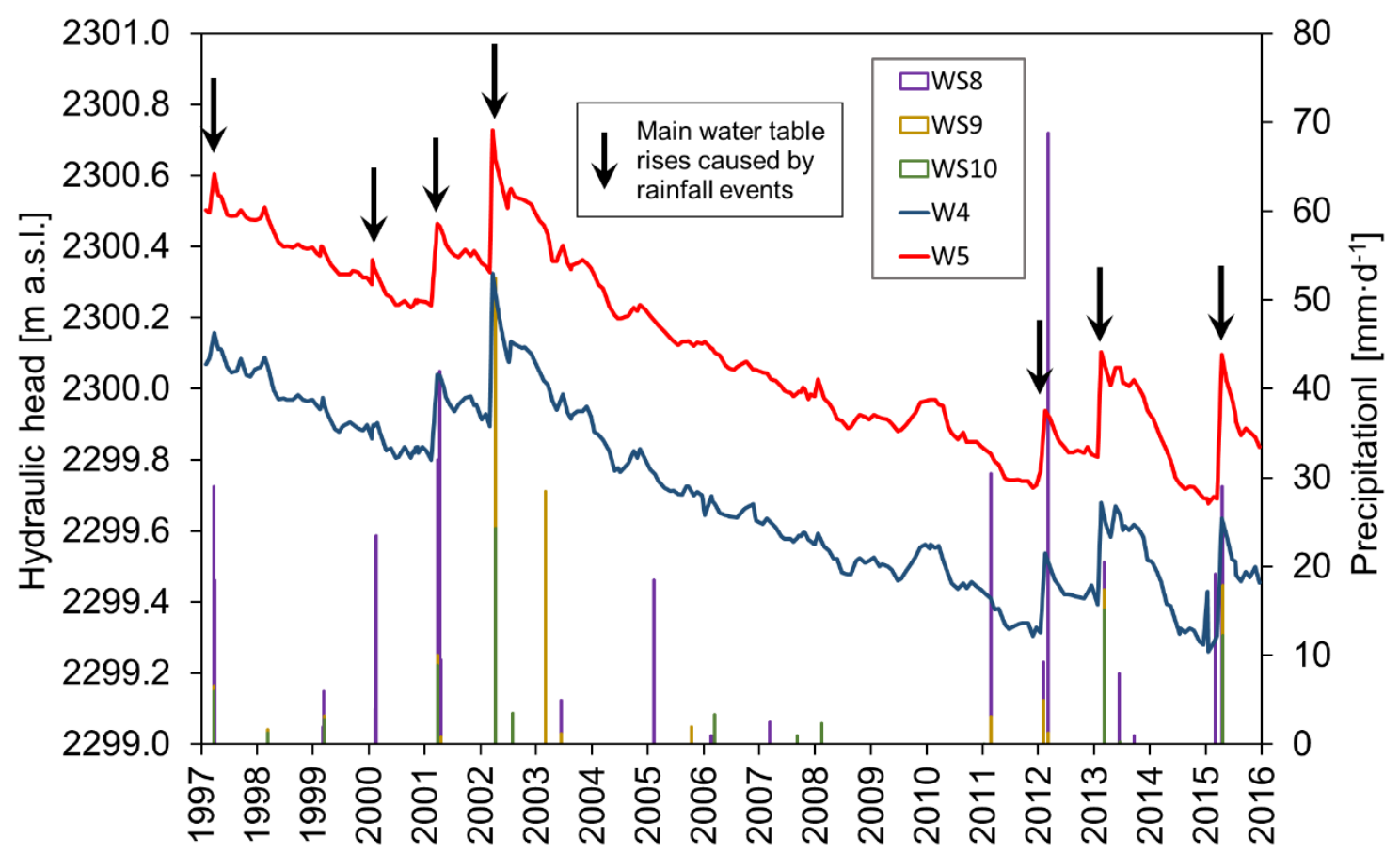

955

956

957

958

959

960 


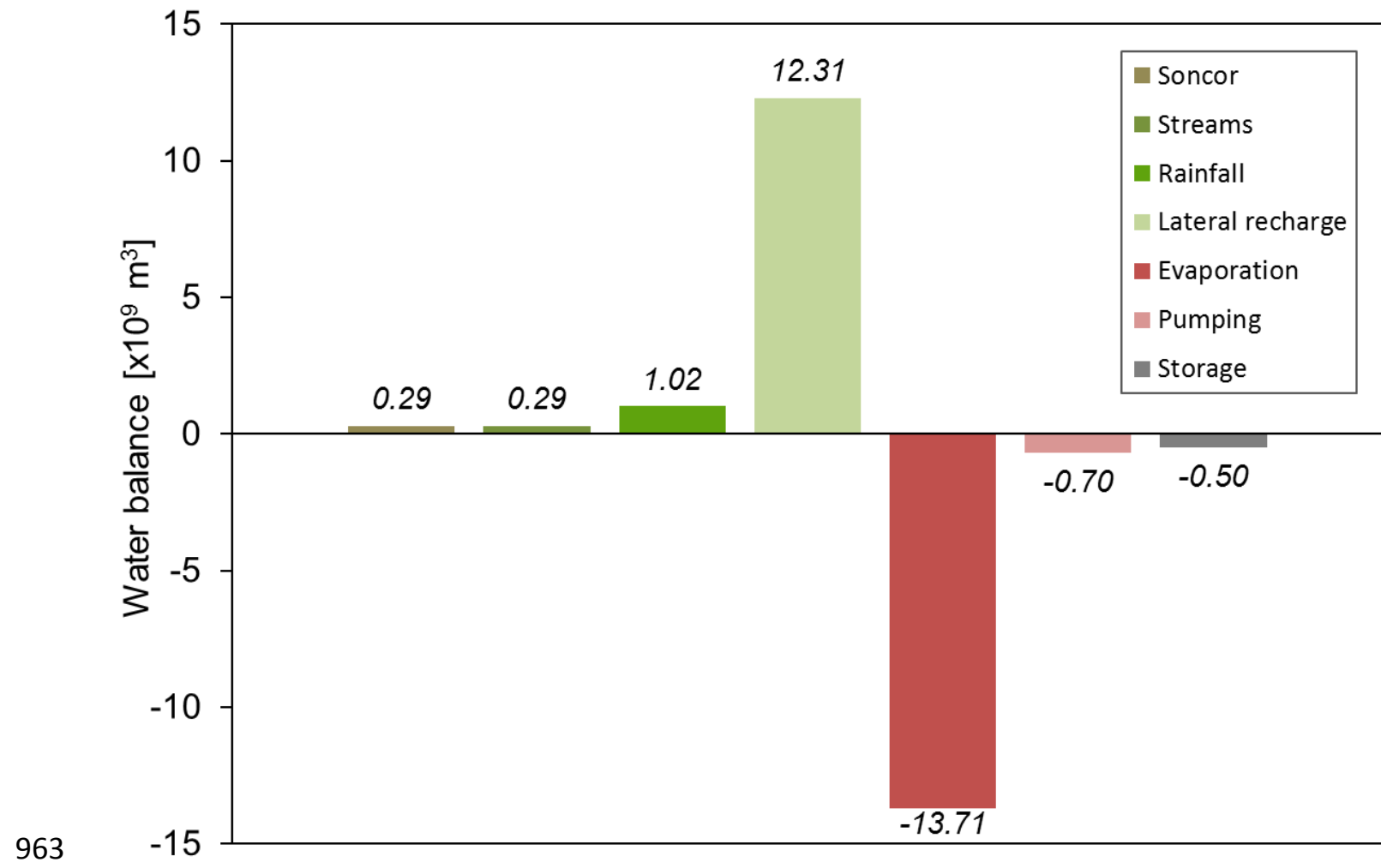

964

965

966

967

968

969

970

971

972

973

974

975

976 

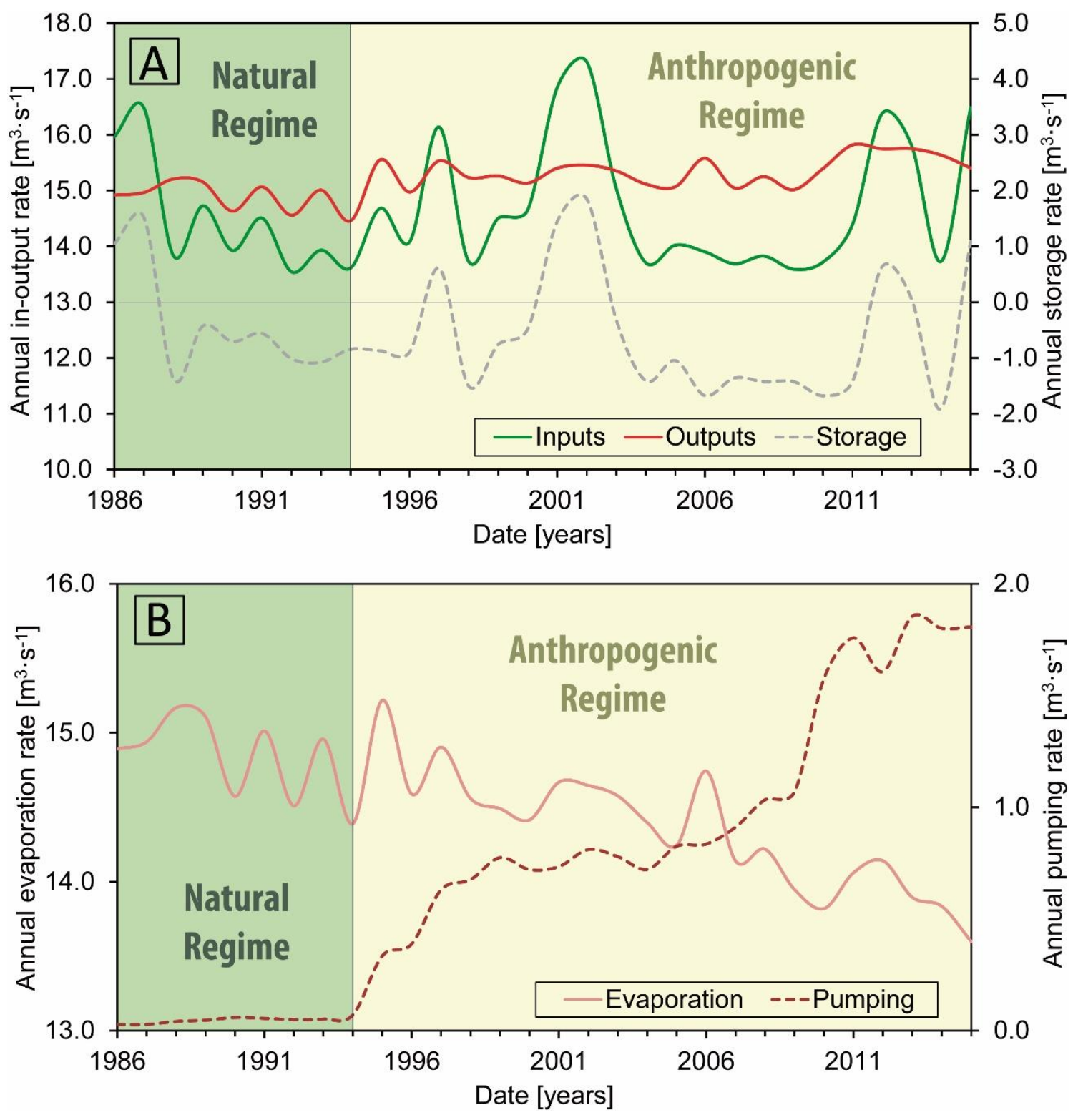


\section{SUPPORTING INFORMATION}

988 Table S1: Rainfall and recharge values for each sub-basin (Marazuela et al., 2019). The sub-basin 989 locations are shown in Figure 3A.

990 Table S2: Rainfall, recharge and evaporation values for each zone of the model domain. The 991 recharge zones locations are shown in Figure 3B (Marazuela et al., 2019).

992 Table S3: Coordinates, in Universal Transverse Mercator (UTM), and flow of each stream 993 (Marazuela et al., 2019).

994 Table S4: Hydraulic conductivity and specific storage values, both initially and calibrated by the 995 numerical model. The location of each zone is shown in Figure 4A.

996 Table S5: Specific storage values, both initially and calibrated by the numerical model. The 997 location of each zone is shown in Figure 4B.

998

999

1000

1001

1002

1003

1004

1005

1006

1007

1008

1009

1010

1011 
TABLE S1

\begin{tabular}{|c|c|c|c|c|c|c|}
\hline SUB-BASIN & AREA $\left[\mathrm{km}^{2}\right]$ & $\begin{array}{l}\text { RAINFALL } \\
{\left[\mathrm{mm} \cdot \mathrm{yr}^{-1}\right]}\end{array}$ & $\begin{array}{l}\text { RAINFALL } \\
{\left[\mathrm{m}^{3} \cdot \mathrm{s}^{-1}\right]}\end{array}$ & $\begin{array}{c}\text { DETENTION } \\
\text { [\%] }\end{array}$ & $\begin{array}{c}\text { ESTIMATED } \\
\text { RECHARGE }\left[\mathrm{m}^{3} \cdot \mathrm{s}^{-1}\right]\end{array}$ & $\begin{array}{c}\text { CALIBRATED } \\
\text { RECHARGE }\left[\mathrm{m}^{3} \cdot \mathrm{s}^{-1}\right]\end{array}$ \\
\hline Rio Grande & 2165 & 95 & 6.54 & 25 & 4.91 & \multirow{2}{*}{6.50} \\
\hline Toconao & 1263 & 77 & 3.07 & 25 & 2.30 & \\
\hline Talabre & 845 & 74 & 1.97 & 25 & 1.48 & 1.48 \\
\hline Socaire & 1574 & 60 & 2.97 & 25 & 2.23 & 2.23 \\
\hline Monturaqui & 3378 & 44 & 4.68 & 25 & 3.51 & 2.15 \\
\hline Altos Pacífico & 1093 & 9 & 0.30 & 85 & 0.05 & \multirow{6}{*}{0.31} \\
\hline Altos W & 354 & 37 & 0.41 & 85 & 0.06 & \\
\hline Borde W & 1575 & 13 & 0.66 & 85 & 0.10 & \\
\hline Cordillera W & 515 & 24 & 0.40 & 85 & 0.06 & \\
\hline Chépica & 91 & 6 & 0.02 & 85 & $<0.01$ & \\
\hline Zona Sur & 521 & 9 & 0.15 & 85 & 0.02 & \\
\hline North Alluvial & 279 & 35 & 0.31 & 35 & 0.20 & \multirow{2}{*}{0.25} \\
\hline North Mixing Zone & 83 & 30 & 0.08 & 35 & 0.05 & \\
\hline
\end{tabular}

1014

1015

1016

1017

1018

1019

1020

1021

1022

1023

1024

1025

1026

1027

1028

1029 
TABLE S2

\begin{tabular}{|c|c|c|c|c|c|c|c|c|c|c|}
\hline \multirow{2}{*}{ ZONE } & \multirow{2}{*}{ SUB-ZONE } & \multirow{2}{*}{$\begin{array}{l}\text { AREA } \\
{\left[\mathrm{km}^{2}\right]}\end{array}$} & \multirow{2}{*}{$\begin{array}{l}\text { RAINFALL } \\
{\left[\mathrm{mm} \cdot \mathrm{yr}^{-1}\right]}\end{array}$} & \multirow{2}{*}{$\begin{array}{c}\text { RAINFALL } \\
{\left[\mathrm{m}^{3} \cdot \mathrm{s}^{-1}\right]}\end{array}$} & \multirow{2}{*}{$\begin{array}{c}\text { DETENTION } \\
\text { [\%] }\end{array}$} & \multirow{2}{*}{$\begin{array}{c}\text { RECHARGE } \\
{\left[\mathrm{m}^{3} \cdot \mathrm{s}^{-1}\right]}\end{array}$} & \multicolumn{2}{|c|}{ EVAPORATION $\left[\mathrm{mm} \cdot \mathrm{yr}^{-1}\right]$} & \multicolumn{2}{|c|}{ EVAPORATION $\left[\mathrm{m}^{3} \cdot \mathrm{s}^{-1}\right]$} \\
\hline & & & & & & & Initial & Calibrated & Initial & Calibrated \\
\hline \multirow{5}{*}{ 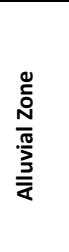 } & A12a & 162 & 23 & 0.12 & 35 & 0.08 & 1 & 1 & 0.01 & 0.01 \\
\hline & $A 12 b$ & 274 & 24 & 0.21 & 35 & 0.14 & 0 & 0 & 0.00 & 0.00 \\
\hline & A12c & 61 & 16 & 0.03 & 35 & 0.02 & 0 & 0 & 0.00 & 0.00 \\
\hline & $A 12 d$ & 57 & 23 & 0.04 & 35 & 0.03 & 0 & 0 & 0.00 & 0.00 \\
\hline & A12e & 202 & 22 & 0.14 & 35 & 0.09 & 1 & 1 & 0.01 & 0.01 \\
\hline \multirow{18}{*}{ 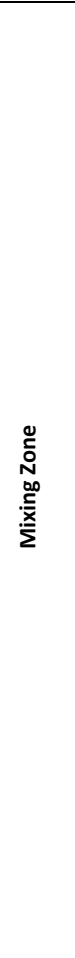 } & A1 & 21 & 24 & 0.02 & 35 & 0.01 & 97 & 113 & 0.06 & 0.07 \\
\hline & A2 & 127 & 25 & 0.10 & 35 & 0.07 & 1066 & 825 & 4.31 & 3.33 \\
\hline & A3 & 90 & 21 & 0.06 & 35 & 0.04 & 744 & 213 & 2.12 & 0.61 \\
\hline & A4 & 114 & 25 & 0.09 & 35 & 0.06 & 97 & 113 & 0.35 & 0.41 \\
\hline & A5 & 268 & 28 & 0.23 & 35 & 0.15 & 97 & 112 & 0.82 & 0.96 \\
\hline & A6 & 34 & 22 & 0.02 & 35 & 0.02 & 1066 & 514 & 1.16 & 0.56 \\
\hline & A7 & 71 & 21 & 0.05 & 35 & 0.03 & 97 & 764 & 0.22 & 1.72 \\
\hline & A8 & 25 & 25 & 0.02 & 35 & 0.01 & 1066 & 952 & 0.83 & 0.75 \\
\hline & A9-1 & 29 & 14 & 0.01 & 35 & 0.01 & 1355 & 174 & 1.27 & 0.16 \\
\hline & A9-2 & 51 & 16 & 0.03 & 35 & 0.02 & 1066 & 411 & 1.73 & 0.67 \\
\hline & A10-2 & 63 & 11 & 0.02 & 35 & 0.01 & 744 & 172 & 1.49 & 0.35 \\
\hline & $\mathrm{BNa}$ & 1 & 21 & 0.00 & 35 & 0.00 & 2190 & 2190 & 0.09 & 0.09 \\
\hline & $\mathrm{BNb}$ & 1 & 21 & 0.00 & 35 & 0.00 & 2190 & 2190 & 0.03 & 0.03 \\
\hline & Chaxa & 1 & 22 & 0.00 & 35 & 0.00 & 2190 & 2190 & 0.02 & 0.02 \\
\hline & Tebenquiche & 2 & 26 & 0.00 & 35 & 0.00 & 2190 & 2190 & 0.14 & 0.14 \\
\hline & Cejar & 1 & 26 & 0.00 & 35 & 0.00 & 2190 & 2190 & 0.02 & 0.02 \\
\hline & Peine & 1 & 16 & 0.00 & 35 & 0.00 & 2190 & 2190 & 0.05 & 0.05 \\
\hline & Tilopozo & 1 & 11 & 0.00 & 35 & 0.00 & 2190 & 2190 & 0.03 & 0.03 \\
\hline \multirow{7}{*}{ 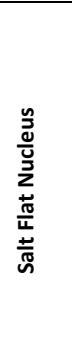 } & A13a & 507 & 8 & 0.13 & 35 & 0.09 & 20 & 20 & 0.33 & 0.33 \\
\hline & $A 13 b$ & 210 & 16 & 0.11 & 35 & 0.07 & 20 & 20 & 0.14 & 0.14 \\
\hline & $A 13 c$ & 178 & 20 & 0.11 & 35 & 0.07 & 20 & 20 & 0.11 & 0.11 \\
\hline & A13d & 260 & 18 & 0.14 & 35 & 0.09 & 20 & 20 & 0.17 & 0.17 \\
\hline & A13e & 273 & 14 & 0.12 & 35 & 0.08 & 20 & 20 & 0.18 & 0.18 \\
\hline & Zi1 & 140 & 22 & 0.10 & 35 & 0.06 & 0 & 7 & 0.00 & 0.03 \\
\hline & Zi2 & 78 & 23 & 0.06 & 35 & 0.04 & 2 & 8 & 0.01 & 0.02 \\
\hline
\end{tabular}

1031

1032

1033

1034

1035

1036 
TABLE S3

\begin{tabular}{|c|c|c|c|}
\hline RIVER or STREAM & UTM East & UTM North & FLOW $\left[\mathbf{m}^{\left.\mathbf{3} \cdot \mathbf{s}^{-1}\right]}\right.$ \\
\hline San Pedro river & 582083 & 7475499 & 0.72 \\
\hline Vilama river & 583595 & 7470601 & 0.28 \\
\hline Jerez stream & 602845 & 7435114 & 0.06 \\
\hline Aguas Blancas stream & 600733 & 7425563 & 0.09 \\
\hline Talabre stream & 623250 & 7420102 & 0.01 \\
\hline Camar & 606284 & 7411161 & 0.01 \\
\hline Socaire stream & 617452 & 7387854 & 0.15 \\
\hline Peine stream & 596005 & 7380506 & 0.01 \\
\hline Tilomonte stream & 590688 & 7368361 & 0.04 \\
\hline
\end{tabular}

1038

1039

1040

1041

1042

1043

1044

1045

1046

1047

1048

1049

1050

1051

1052

1053

1054

1055 
TABLE S4

\begin{tabular}{|c|c|c|c|c|}
\hline \multirow{2}{*}{ UNIT } & \multirow{2}{*}{ DOMAIN } & \multirow{2}{*}{ ZONE } & \multicolumn{2}{|c|}{ HYDRAULIC CONDUCTIVITY $\left[\mathrm{m} \cdot \mathrm{d}^{-1}\right]$} \\
\hline & & & REFERENCE VALUE & CALIBRATED \\
\hline \multirow{29}{*}{ 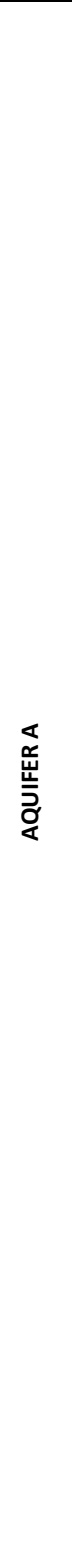 } & \multirow{11}{*}{ Mixing Zone } & KA1 & 100 & 80 \\
\hline & & KA2 & 100 & 220 \\
\hline & & KA3 & 100 & 150 \\
\hline & & KA4 & 100 & 200 \\
\hline & & KA5 & 100 & 60 \\
\hline & & KA6 & 100 & 300 \\
\hline & & KA7 & 100 & 225 \\
\hline & & KA8 & 100 & 190 \\
\hline & & KA9 & 100 & 190 \\
\hline & & KA11 & 100 & 190 \\
\hline & & Lakes & 10000 & 10000 \\
\hline & \multirow{9}{*}{ Alluvial fans } & KA10a & 100 & 100 \\
\hline & & KA10b & 100 & 80 \\
\hline & & KA10c & 100 & 80 \\
\hline & & KA10d & 100 & 80 \\
\hline & & KA10e & 100 & 80 \\
\hline & & KA10f & 100 & 80 \\
\hline & & KA10g & 100 & 200 \\
\hline & & KA10h & 100 & 300 \\
\hline & & KA10i & 100 & 250 \\
\hline & & KA12a & 200 & 300 \\
\hline & & KA12b & 200 & 140 \\
\hline & & KA12c & 200 & 160 \\
\hline & & KA12d & 200 & 160 \\
\hline & Salt flat Nucleus & KA12e & 200 & 100 \\
\hline & & KA12f & 200 & 100 \\
\hline & & KA12g & 200 & 100 \\
\hline & & KA12h & 200 & 140 \\
\hline & & KA12i & 200 & 140 \\
\hline \multirow{6}{*}{ 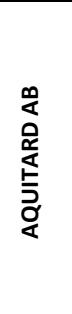 } & \multirow{5}{*}{$\begin{array}{l}\text { Mixing Zone and } \\
\text { alluvial fans }\end{array}$} & KAB-1 & 0.1 & 0.01 \\
\hline & & KAB-2 & 1 & 2 \\
\hline & & KAB-3 & 1 & 5 \\
\hline & & KAB-4 & 1 & 2 \\
\hline & & KAB-5 & 1 & 5 \\
\hline & Salt flat Nucleus & KAB-6 & 0.1 & 0.01 \\
\hline \multirow{6}{*}{ 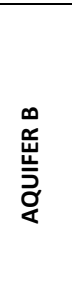 } & \multirow{5}{*}{$\begin{array}{l}\text { Mixing Zone and } \\
\text { alluvial fans }\end{array}$} & KB-1 & 1 & 1 \\
\hline & & KB-2 & 10 & 20 \\
\hline & & KB-3 & 10 & 20 \\
\hline & & KB-4 & 10 & 20 \\
\hline & & KB-5 & 10 & 20 \\
\hline & Salt flat Nucleus & KB-6 & 1 & 0.1 \\
\hline
\end{tabular}


TABLE S5

\begin{tabular}{|c|c|c|c|}
\hline \multirow{2}{*}{ HYDROSTRATIGRAPHIC UNIT } & \multirow{2}{*}{ ZONE } & \multicolumn{2}{|c|}{ SPECIFIC STORAGE $\left[\mathrm{m}^{-1}\right]$} \\
\hline & & INITIAL VALUE & CALIBRATED \\
\hline \multirow{14}{*}{ AQUIFER A } & SsA1 & $0.004-0.012$ & 0.007 \\
\hline & SsA2 & $0.004-0.012$ & 0.012 \\
\hline & SsA3 & $0.004-0.012$ & 0.01 \\
\hline & SsA4 & $0.004-0.012$ & 0.01 \\
\hline & SsA5 & $0.004-0.012$ & 0.01 \\
\hline & SsA6a & $0.001-0.005$ & 0.011 \\
\hline & SsA6b & $0.001-0.005$ & 0.01 \\
\hline & SsA6c & $0.001-0.005$ & 0.011 \\
\hline & SsA6d & $0.001-0.005$ & 0.011 \\
\hline & SsAGe & $0.001-0.005$ & 0.011 \\
\hline & SsAGf & $0.001-0.005$ & 0.01 \\
\hline & SsA6g & $0.001-0.005$ & 0.01 \\
\hline & SsA6h & $0.001-0.005$ & 0.01 \\
\hline & SsA6i & $0.001-0.005$ & 0.01 \\
\hline AQUITARD AB & SsAB & 0.0001 & 0.0001 \\
\hline AQUIFER B & SsB & 0.00001 & 0.00001 \\
\hline
\end{tabular}

1059

1060

1061

1062

1063

1064

1065

1066

1067

1068

1069

1070

1071

1073 